\title{
Criteria and geological setting for the generic geothermal underground research laboratory, GEOLAB
}

\author{
Eva Schill ${ }^{1 *}$, Jörg Meixner ${ }^{2}$, Carola Meller², Manuel Grimm², Jens C. Grimmer², Ingrid Stober ${ }^{2}$ and Thomas Kohl²
}

*Correspondence:
eva.schill@kit.edu
${ }^{1}$ Institute for Nuclear
Waste Disposal, Karlsruhe
Institute of Technology,
Hermann-von-Helmholtz-Platz
1,76128 Karlsruhe, Germany
Full list of author information
is available at the end of the
article

${ }^{*}$ Correspondence: eva.schill@kit.edu Waste Disposal, Karlsruhe Institute of Technology, Hermann-von-Helmholtz-Platz 1,76128 Karlsruhe, Germany

\begin{abstract}
High flow rate injection and related hydromechanical interaction are the most important factors in reservoir development of Enhanced Geothermal Systems (EGS). GeoLaB, a new generic geothermal underground research laboratory (URL), is proposed for controlled high flow rate experiments (CHFE) to address limited comprehension of coupled processes connected to EGS reservoir flow conditions. As analogue for typical EGS development, CHFE require specific hydromechanical conditions including a connected fracture network in crystalline basement rock, sufficient hydraulic fracture transmissivities, a strike-slip to normal faulting tectonic regime, controllable hydraulic boundary conditions, and hydrothermal alteration fracture fillings that improve conditions for hydromechanical interaction. With the aim to identify most appropriate areas for future site selection, four criteria have been established based on the EGS reference site of Soultz. Two URLs in crystalline basement worldwide approximate the requirements of a new generic GeoLaB and may be used for accompanying experimentation. Besides favourable geological, hydraulic, and stress conditions, the vicinity to long-term EGS production favours the southern Black Forest as potential region for GeoLaB. Therefore, an exemplary site assessment has been carried out at "Wilhelminenstollen" in the southern Black Forest (Germany). New remote sensing, hydrochemical, and geophysical analyses as well as reactivation potential, and stress modelling were added to complement existing geological and hydrogeological information. At this site, reactivation potential analysis reveals two local maxima prone for shear reactivation as strike-slip faults. The highest lineament density is observed for the N110 $\mathrm{E}$ strike direction that is associated with both slip and dilation tendency maxima. Clay minerals occur in fractures and the matrix. Local, partly water-bearing fractures, when partly filled with ore minerals, were connected to veins in the tunnel using shallow geophysical methods. Hydrochemical data reveal infiltration of the tunnel water from at least $500 \mathrm{~m}$ above the tunnel. The results suggest a crystalline basement with a fracture network that is regionally connected and water-conducting. Hydraulic conductivity in the southern Black Forest granite is estimated to amount to about $4.5 \cdot 10^{-8} \mathrm{~m} \mathrm{~s}^{-1}$ at $500 \mathrm{~m}$ depth. The hydraulic boundary conditions exclude unknown drainage. Analyses of the influence of topography on orientation and magnitude of the maximum stress indicate a minimum overburden of about $500 \mathrm{~m}$ for regional reactivation to be valid. In conclusion, the southern Black Forest and in particular "Wilhelminenstollen" offers favourable condition for CHFE. Final decision on the GeoLaB site is to be drawn from forthcoming exploration wells.
\end{abstract}

Keywords: Geothermal underground research laboratory, Fractured crystalline basement, Black forest, GeoLaB 


\section{Background}

Most geothermal resources worldwide are found in fractured crystalline basement and may be approached using enhanced geothermal systems (EGS) technology (e.g. MIT 2006). This technology dates back to the 1970s, when first hot dry rock (HDR) projects led to the design of artificial sub-surface heat exchangers in crystalline basement rock. The outcome of the Fenton Hill HDR experiment (1970-1995, Los Alamos National Laboratory, USA) was the identification of the hydraulic challenges related to reservoir creation (Brown 2009). Reservoir testing and development revealed that the characteristics of the crystalline basement appear to be highly variable. Some of the related questions have been addressed along the EGS learning curve, particularly at the Soultz-sous-Forêts EGS site and during its follow-up projects. With regard to productivity enhancement of fractured granitic basement, different injection schemes and operation modes have been tested and validated with respect to their efficiency (Nami et al. 2008; Schill et al. 2015). Cyclic injection along with production from a second well has been found to be most effective for reservoir development (Schindler et al. 2010; Schill et al. 2015). Due to perceptible induced seismicity, however, the deep reservoir at Soultz has mainly been treated chemically in the late stage of the development phase. During operation of the Soultz power plant, occurrence of induced seismicity was reduced in frequency and magnitude by distributing the injected volume over different injection points and limiting the overall flow rate (Cuenot et al. 2011). Still, high flowrate injection is a crucial issue for large-scale industrial development and economic viability of EGS.

As such, current EGS development for controlled enhancement of the reservoir is hindered by fundamental understanding of processes occurring at high volumes and rates of flow in fractured reservoir rocks. Additional complexity results among others from high differential stresses, the related mechanical behaviour, and the chemical response of the fluid. Although experimental progress has been made, fundamental constitutive laws of flow and thermo-hydraulic-mechanical-chemical (THMC) coupling presently are not being considered adequately in reservoir engineering and plant operation in fractured environments. It is, therefore, most important to carry out large-scale in situ tests under hydrogeological conditions and comprehensively study these aspects (Freeze and Javandel 2008).

\section{Necessity for real-scale experiments}

Brady and Brown (2006) detail five inherent complexities in rock mechanical investigation: (1) fracture mechanics, (2) scale effects, (3) tensile strength, (4) fluid interaction, and (5) alteration. Although being established already 20 years ago these are still most important mechanics topics and remain key aspects in characterising the mechanical influence in a reservoir. They involve especially the bias in evaluation of laboratory and field data in terms of the natural complexity of heterogeneity of the host rock but also of the complexity flow pathways. Out of a large assessment, two aspects may be picked out to describe the need for research in a reservoir simulator.

Scale effects are a well-known limitation in describing mechanical processes in subsurface rock since they may exhibit tremendous changes in strength when varying the sample sizes under laboratory conditions. Peak strength of rock, a key parameter separating the linear from the failure regime (i.e. involving possible seismicity), is highly dependent 
of rock sample size. Barton et al. (1985) have identified variabilities by more than $50 \%$ by direct shear test with smaller sample sizes involving considerably higher peak strength than larger samples.

The origin of wing-crack mechanisms and their evolution within a shear zone during a stimulation as proposed by Jung (2013) addresses another challenge in reservoir simulation rarely performed in rock mechanics due to not existent opportunities. It involves the creation of new void spaces by the injection of large fluid volumes. Identical mechanisms to wing-cracks in structural geology are proposed when injecting large amounts of fluid in host rock. Under a given stress regime, wing-cracks within a shear zone could connect consecutively in a shear zone until forming tensile fractures.

Besides mechanical interaction, hydraulic effects from high reservoir flow rates need to be studies more in detail to investigate the range of validity for the typically assumed Darcy flow and fluid dynamics need to be carefully evaluated. Zimmerman and Yeo (2000) have shown that the Stokes equations for laminar flow leave their range of validity from $R e>10$ and new Navier-Stokes solvers need to be applied. In a heterogeneous network with tube-like structures at the interface of fractures (Wennberg et al. 2016) these conditions are easily met and apparent transmissivity decreases with higher flowrate. Until now, there are ample theoretical and numerical considerations of the flow behaviour in fractured rock; however, little was done to quantify these effects in laboratories or under real field conditions (Kohl et al. 1997).

The implications on hydraulic field and rupture mechanisms are obvious and can be easily extended to thermal and chemical impacts. Therewith, injection in fractured reservoirs can include a high variety of interactions induced from hydraulic fields (Gaucher et al. 2015), known as THMC for thermal, hydraulic, mechanical, and chemical interaction (Kolditz et al. 2012). It is most important to address these questions during large-scale observation to calibrate coupled mechanical models also from real experimental testing under reservoir condition. Providing the specific experimental background going beyond the expertise from nuclear research and applying new probabilistic based approaches are important perspectives for reservoir engineering. Careful analyses of probabilistic response spectra together with geological structural analysis resulting in new hydraulic calibration parameters of fracture network models under variable flow rate can only be performed in a 3D environment where processes are monitored in space and time. In this context, underground research laboratories (URLs) are best suited to monitor and quantify the interrelated processes during large volume injection in fractured rock by large-scale in situ observational methods to complement presentday laboratory-scale experiments. Such experimental facilities for application and monitoring of experiments should address key aspects of a safe and economically efficient use of geothermal energy.

\section{Experiments in a geothermal URL}

In-line with related geo-disciplines, such as nuclear waste disposal research, we propose a specific URL for geothermal purposes, which is to be located in a typical EGS environment to conduct fundamental experiments in space and time (i.e. 4D). As pointed out by NEA (2013) for nuclear waste disposal research, URLs offer an excellent opportunity to integrate multiple disciplines (e.g. geology, hydrology, and engineering), build 
technical teams, and gain practical experience that will be invaluable for the next generation of researchers. Decision-making requires practical demonstrations of key technical elements to prove the robustness of the proposed concept as well as to establish confidence in the technology. URLs play an important and multi-faceted role in these scientific assessments and demonstrations, since they provide a realistic environment for characterising and testing the selected technical approaches and materials. In areas of operational safety, acquiring geological information on the repository scale, and constructional and operational feasibility, only URLs can provide reliable in situ data. URLs can also provide tangible benefits in enhancing participation by the general scientific community and confidence of both technical and non-technical stakeholders. The many successful URLs operated for other research purposes reflect their high value.

The 4D controlled high flow rate experiments (CHFE) in a geothermal URL may address the validity of fundamental flow and hydro-mechanical laws in fractured rock, i.e. on surfaces of variable roughness and tortuosity, and shall provide new insights into the relevant petrophysical, hydrogeological, and mechanical processes in space and time. A typical experiment may include fluid injection into an appropriate fracture zone underneath the URL (Fig. 1). Measurement devices in observation wells and on the surface enable full 3D process monitoring and can be adapted to different experiments and scientific purposes. Furthermore, the URL may provide access to a modified surface for further investigation. A schematic setting of the planned geothermal URL, GeoLaB, is shown in Fig. 1. Our concept of such an infrastructure facility includes a 1-2 km long tunnel with 3-4 side caverns, from which the CHFEs and other key experiments can be performed (Fig. 1b).

In order to prepare the site selection for GeoLaB, in this study, we establish criteria for a generic geothermal URL for CHFE. Applying these criteria to existing URLs, we demonstrate the necessity for a new generic URL. Based on these results, the Southern Black Forest appears to reveal appropriate conditions and is selected for further investigation. Furthermore, the study includes a review of suitable existing mines in the Black Forest. Since it is crucial to install the GeoLaB in an environment close to hydraulic reservoir conditions, the detailed planning concept needs to follow the tectonic setting in the adjacent rock. Especially, the structure of the target fault zone imposes boundary

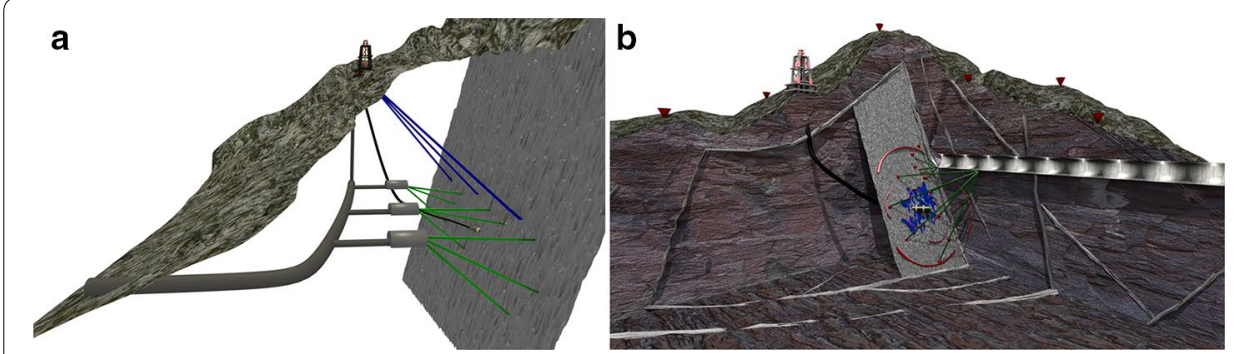

Fig. 1 a Possible layout of the planned geothermal URL (not to scale), GeoLaB, with an access tunnel to a fracture zone, three experimental caverns, and exploration wells (blue) and observation wells (green) from the tunnel into the fracture zone. In addition to the monitoring stations (red cones), the main injection well (black) for controlled high-flow experiments (CHFE) is reached from surface boreholes targeting the fracture zones next to experimental caverns. b Possible CHFE with high flow rate injection from the surface into a fracture zone (blue volume) and related mechanical deformation indicated by red ring segments 
conditions on URL construction and the installation of tools to achieve the scientific targets. In this study, we describe an exploration procedure aiming at the characterisation of a fault zone in a target rock that is predestined for geothermal production in central Europe. In this respect, a case exploration study is carried out at "Wilhelminenstollen" in the southern Black Forest, assuming an extension of existing mining structures for construction of a geothermal URL. Based on the results the necessary exploration steps towards a test site in the Variscan crystalline rock are detailed.

\section{Criteria for a generic geothermal URL}

In analogy to the procedure chosen in nuclear waste disposal research, it is distinguished between "generic" scientific investigations in analogue URLs and "site-specific" geothermal URLs linked to a real operation (NEA 2013). In geothermal research, site-specific investigations are to be conducted under real conditions in the deep subsurface using tomographic approaches between geothermal wells (e.g. DOE FORGE project, http:// www.energy.gov/eere/forge). Complementary, GeoLaB is intended to be developed as generic URL to gain general experience with respect to geological, physical, and chemical processes under high flow rate conditions, including model testing and verification of investigation and measurement techniques and to identify process interactions by means of experiments. Generic URLs are to be installed in the host rock type, but not in the particular geological formation. Although closely mimicking hydraulic or geological reservoir conditions, generic geothermal URLs are not able to reproduce parameters, such as temperature, stress magnitude, and geochemistry in a specifically selected host rock formation.

A geothermal URL designed for CHFE is associated with specific requirements on hydraulic and geological properties of typical EGS reservoirs and, hence, on the GeoLaB site. EGS technology is best studied in the Upper Rhine Graben (URG). This accounts for the Soultz project, the unique proto-type of EGS, in particular, since nowhere else worldwide so many hydromechanical stimulation experiments of different type have been accomplished. Lithologic, hydraulic, and stress conditions in a geothermal URL should thus be comparable to conditions encountered there, but also be transferrable to the crystalline basement of Central Europe and worldwide. Note that URG's host rocks are exposed in the adjacent low mountain ranges. Against this background, we aim at installing GeoLaB at a site approximating Soultz condition to reduce the number of degrees of freedom when comparing results of CHFE to reservoir experiments. Furthermore, since only few developed EGS sites exist worldwide, the definition of a typical EGS environment is based on the theoretical considerations of Garnish (2002) and the Soultz-sous-Forêts EGS project.

\section{EGS reference Soultz-sous-Forêts}

The Soultz site is located in the southern part of the URG's thermal anomalies (Baillieux et al. 2013). The reservoir in Soultz comprises two different granite varieties:

- a porphyritic K-feldspar monzogranite (from 1420 to $4700 \mathrm{~m}$ ) with a highly altered and fractured intermediate section (between about 2700 and $3900 \mathrm{~m}$ ) having a fracture densities of up to $2.86 \mathrm{~m}^{-1}$ for fractures with an acoustic aperture of $>1-2 \mathrm{~mm}$ is 
observed in the upper part (Genter and Castaing 1997; Dezayes et al. 2005). A correlation between alteration zones and permeable fractures as well as an increased tendency to shear during stimulation was found for this section (e.g. Evans et al. 2005).

- In the lower part (from 4700 to $5000 \mathrm{~m}$ ) a two-mica granite with fracture densities of up to $1.97 \mathrm{~m}^{-1}$ is observed (Dezayes et al. 2005).

In the granitic basement at the Soultz site, three reservoir levels have been developed at about 2000, 3500, and $5000 \mathrm{~m}$ depth. The different reservoirs fulfil most of the EGS criteria (Table 1) as defined by Garnish (2002). The upper reservoir extending from the top of the basement at $1420 \mathrm{~m}$ depth down to about $2000 \mathrm{~m}$ includes an approximately $100 \mathrm{~m}$ thick alteration zone at its top. This zone is mainly characterised by precipitated hematite, low magnetic susceptibility (Rummel and König 1991), high electric conductivity (Geiermann and Schill 2010), and high values of heat production of up to $7 \mu \mathrm{W} \mathrm{m}{ }^{-3}$ (Pribnow 2000). As regards reservoir engineering, at the Soultz site, about 35 major injection and production experiments have been carried out, during which different types of hydraulic and chemical stimulations were tested and evaluated for their effectiveness (Schill et al. 2015). Thus, Soultz can be considered a reference EGS site.

The production temperatures are higher than $140{ }^{\circ} \mathrm{C}$, the stimulated rock volume is larger than $2 \cdot 10^{8} \mathrm{~m}^{3}$, hydraulic impedance is lower than $0.1 \mathrm{MPa} \mathrm{kg}^{-1} \mathrm{~s}^{-1}$ (in the wells GPK1 and GPK2), and the produced fluid can be re-injected to the complete extent. The effective heat exchange area has not been estimated. The crucial flow rate of $50-100 \mathrm{~L} \mathrm{~s}^{-1}$ was not reached in Soultz. On the contrary, it had to be reduced to about $15 \mathrm{~L} \mathrm{~s}^{-1}$ in 2013 (Schill et al. 2015). Overall hydraulic conductivity in the non-stimulated reservoirs ranges from $1.2 \cdot 10^{-9} \mathrm{~m} \mathrm{~s}^{-1}$ in the upper to $2 \cdot 10^{-8} \mathrm{~m} \mathrm{~s}^{-1}$ in the intermediate to $<2 \cdot 10^{-9} \mathrm{~m} \mathrm{~s}^{-1}$ in the deep reservoir. Separating the most permeable fracture at $3490 \mathrm{~m}$ depth from the test section reduces the hydraulic conductivity by one order of magnitude to about $1 \cdot 10^{-9} \mathrm{~m} \mathrm{~s}^{-1}$ in the intermediate reservoir (Jung et al. 1995). Hydraulic conductivities in the fractured zone between 2850 and $3100 \mathrm{~m}$ were determined to be

Table 1 Requirements to be met by EGS according to Garnish (2002) and reservoir parameters of the Soultz-sous-Forêts EGS

\begin{tabular}{|c|c|c|c|}
\hline & EGS requirement & Soultz $3.5 \mathrm{~km}$ reservoir & Soultz $5 \mathrm{~km}$ reservoir \\
\hline Flow rate $\left(L s^{-1}\right)$ & $50-100$ & 24 & 23 \\
\hline $\begin{array}{l}\text { Mean wellhead fluid } \\
\text { temperature }\left({ }^{\circ} \mathrm{C}\right)\end{array}$ & $150-200$ & 140 & 157.5 \\
\hline Effective heat exchange area & $>2 \cdot 10^{6} \mathrm{~m}^{2}$ & N/A & $\mathrm{N} / \mathrm{A}$ \\
\hline Rock volume $\left(\mathrm{m}^{3}\right)$ & $>2 \cdot 10^{8}$ & About $7 \cdot 10^{8}$ & About $2.7 \cdot 10^{9}$ \\
\hline \multirow[t]{4}{*}{ Hydraulic impedance } & $<0.1 \mathrm{MPa} \mathrm{L}^{-1} \mathrm{~S}^{-1}$ & $\begin{array}{l}0.06 \mathrm{MPa} \mathrm{L}^{-1} \mathrm{~S}^{-1} \\
(\mathrm{GPK} 1 \text {, injection) }\end{array}$ & $\begin{array}{l}0.1 \mathrm{MPa} \mathrm{L}^{-1} \mathrm{~S}^{-1} \text { (GPK1, } \\
\text { injection) }\end{array}$ \\
\hline & & $\begin{array}{l}0.06 \mathrm{MPa} \mathrm{L}^{-1} \mathrm{~s}^{-1} \\
\text { (GPK2, production) }\end{array}$ & $\begin{array}{l}0.05 \mathrm{MPa} \mathrm{L}^{-1} \mathrm{~s}^{-1} \\
\text { (GPK2, production) }\end{array}$ \\
\hline & & & $\begin{array}{l}0.25 \mathrm{MPa} \mathrm{L}^{-1} \mathrm{~S}^{-1} \\
(\mathrm{GPK} 3, \text { injection) }\end{array}$ \\
\hline & & & $\begin{array}{l}0.25 \mathrm{MPa} \mathrm{L}^{-1} \mathrm{~s}^{-1} \\
\text { (GPK4, production) }\end{array}$ \\
\hline Water loss at the surface & $<10 \%$ & $0 \%$ (Total reinjection) & $0 \%$ (Total reinjection) \\
\hline
\end{tabular}


up to $6 \cdot 10^{-8} \mathrm{~m} \mathrm{~s}^{-1}$ (Sausse et al. 2006). The lower limit of hydraulic conductivity of the matrix is $>10^{-11} \mathrm{~m} \mathrm{~s}^{-1}$ (Rummel and König 1991).

During reservoir development, the factors determining the effectiveness of hydraulic stimulation are the injection volume, downhole pressure, flow rate, injection scheme, and the ambient stress field. The stress field at the Soultz site was determined using drilling-induced tensile fractures and borehole breakouts (Valley and Evans 2007) as well as additional seismic information (Cornet et al. 2007). Mean orientations of the maximum principal stress component $\left(S_{\mathrm{H} \max }\right)$ of $169 \pm 14^{\circ}$ and $175 \pm 10$ obtained by means of the respective methods. The stress field at Soultz is characterised by a transition from normal faulting (NF) to the strike slip regime (SS) at a depth of about $3200 \mathrm{~m}$. In the NF regime of the upper and intermediate reservoirs, maximum slip tendency coincides with the orientation of $S_{\mathrm{Hmax}}$, while maxima are forecast at conjugated angles of $30^{\circ}$ to $S_{\mathrm{Hmax}}$ in the SS regime of the intermediate and deep reservoirs. With respect to the reactivation potential, these structural trends are most favourably oriented in the ambient state of stress (Fig. 2). Hence, they are supposed to control subsurface fluid flow and associated reservoir processes in Soultz.

The significance of such regional forecast for reservoir processes was verified by observations made during different hydraulic stimulation experiments. For example, the 00JUN30 stimulation of GPK2 well below the NF/SS transition zone (open hole section: $4402-5026 \mathrm{~m}$ ) in June/July 2000 caused an overall seismic cloud comprising about 7200 single events. Maximum orientation of this cloud is oriented parallel to $S_{\mathrm{Hmax}}$ (Hettkamp et al. 2004). Although stress re-orientation close to fault zones is not taken into account, the distribution of the failure plane orientations (Fig. 3) follows the distribution expected on the basis of slip and dilation tendency analyses.

The geothermal reservoir at the Soultz site has experienced significant fracturing and complex alteration since Variscan times. The resulting distinct fracture networks provided pathways for hydrothermal fluids, thus enabling fluid-rock interactions between geothermal brines and reservoir rocks. Pervasive and localised vein alterations can be distinguished in the reservoir rocks. An early propylitic, weak iso-chemical alteration of the matrix without a change of the granite texture incorporates partial transformation of biotite and hornblende into chlorite, the replacement of plagioclase by illite, and the formation of hydrogarnet and epidote within the granite (Genter et al. 2000). A second alteration includes strong chemical and textural changes mainly within and in the immediate vicinity of fractures (Fig. 4). Alteration ranges from moderate to extreme grades (e.g. Meller et al. 2014). Typically, a brecciated and cataclased zone is observed between the protolith and a central, often-sealed quartz vein. Here, primary silicates, such as feldspar and biotite, were transformed into clay minerals, with the original texture of the granite being destroyed by shearing. The precipitation in veins contains secondary quartz, barite, illite, carbonates, iron oxides, and, locally, mixed-layers of illite-smectite and chlorite-smectite (Genter et al. 2000; Schleicher et al. 2006). In some altered zones, quartz, biotite, plagioclase, and hornblende are dissolved completely (Ledésert et al. 2010).

The average porosity of the fresh granite is $<1 \%$ (Genter et al. 2000). For hydrothermally altered samples, they determined porosities of 1.7-25\% (often higher than those of breccia and microbreccia) using mercury porosity measurements. The porosity of 


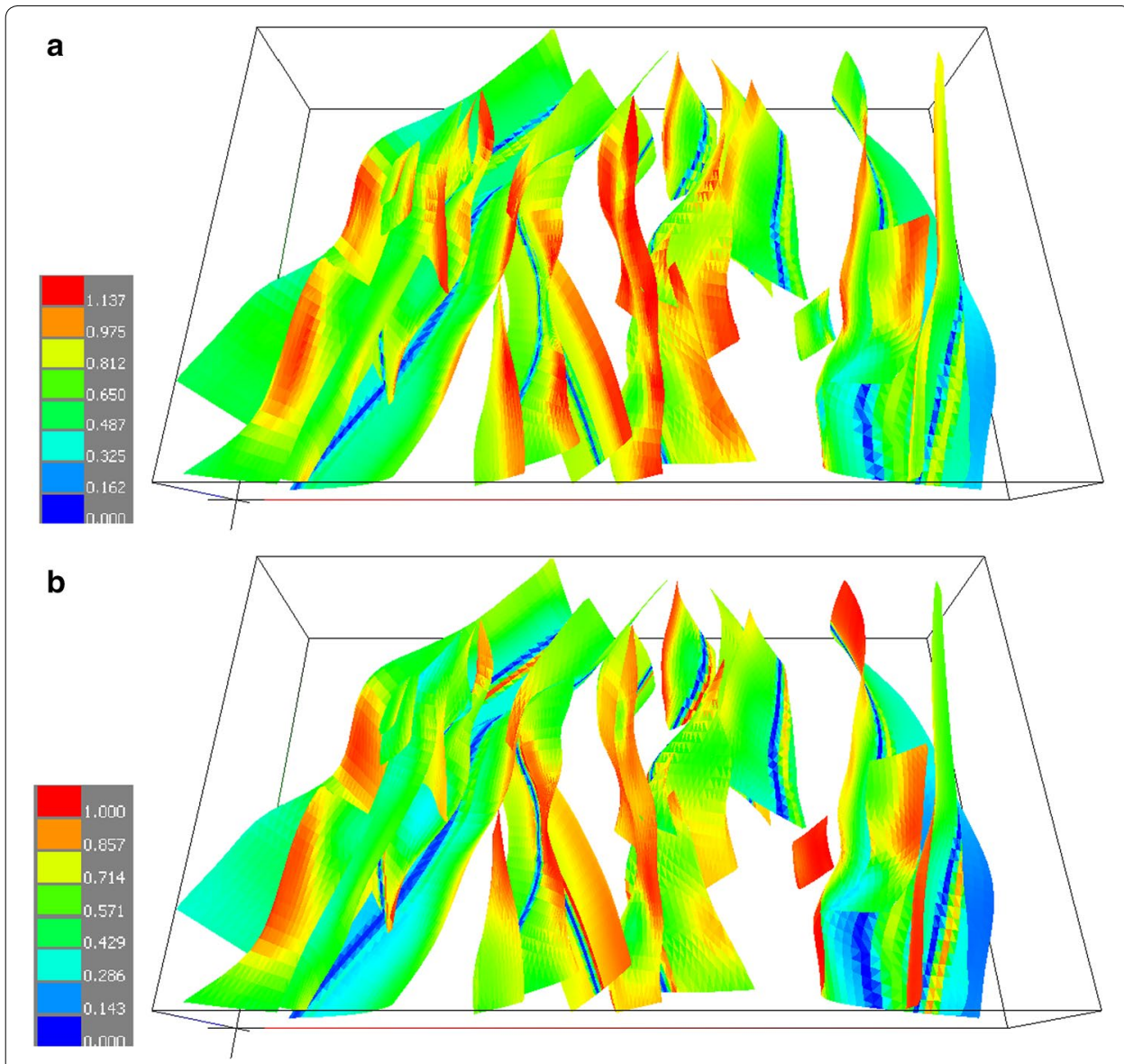

Fig. 2 Slip tendency (a) and dilation tendency (b) for the Soultz EGS site based on the 3D geological model of Baillieux et al. (2014) under transitional faulting regime (NF/SS)

altered plagioclase, which makes up to $40 \%$ of the rock volume (Ledésert et al. 1999), is between 20 and $27 \%$.

Fracture apertures were determined using different techniques. Electric apertures obtained from azimuthal resistivity images range from about $1 \mu \mathrm{m}$ to $1 \mathrm{~mm}$ (Sausse and Genter 2005). Apertures for the upper reservoir were determined from three different core samples (Sausse 2002). Strongly altered granite with chlorite sealing (from $1557.8 \mathrm{~m}$ depth) revealed a mean aperture of $0.448 \pm 0.101 \mathrm{~mm}$. Weakly altered granite with hematite sealing (from $1789.6 \mathrm{~m}$ depth) was found to have a mean aperture of $0.518 \pm 0.257 \mathrm{~mm}$ and unaltered granite with drilling-induced fractures (from $2075.46 \mathrm{~m}$ depth) had a mean aperture of $0.748 \pm 0.101 \mathrm{~mm}$. An upper limit of apertures is given by the width of the fault-related damage and alteration zones (Massart et al. 2010). For the largest group of fractures with a mean lateral extension of about $2700 \mathrm{~m}$, a mean width of damage/alteration zone of about $6 \mathrm{~m}$ of (with a maximum width of $13 \mathrm{~m}$ ) was determined by analysing UBI logs. With decreasing fault size, the relation between extension and width follows a power-law distribution.

Mechanical weakening of rock in hydrothermal alteration zones and the influence of hydrothermally altered fluid pathways are significant for hydro-mechanical processes (e.g. Meller and Kohl 2014; Sausse 2002; Zoback et al. 2012). E-moduli of hydrothermally 


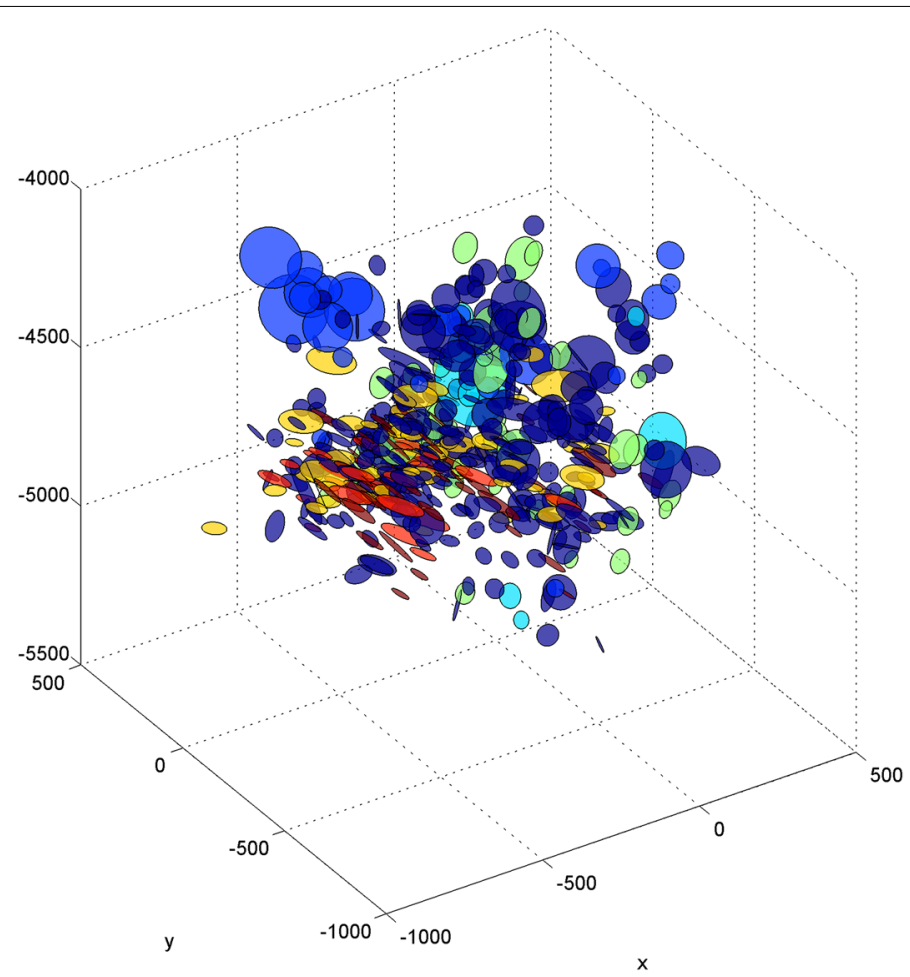

Fig. 3 Orientation and size of the failure planes during the stimulation 00JUN30 of the GPK2 open hole section from 4431 to $5084 \mathrm{~m}$ including 7200 registered and 715 located events, with focal plane solution, modified after Schoenball et al. (2012). Colour indicates different fracture families

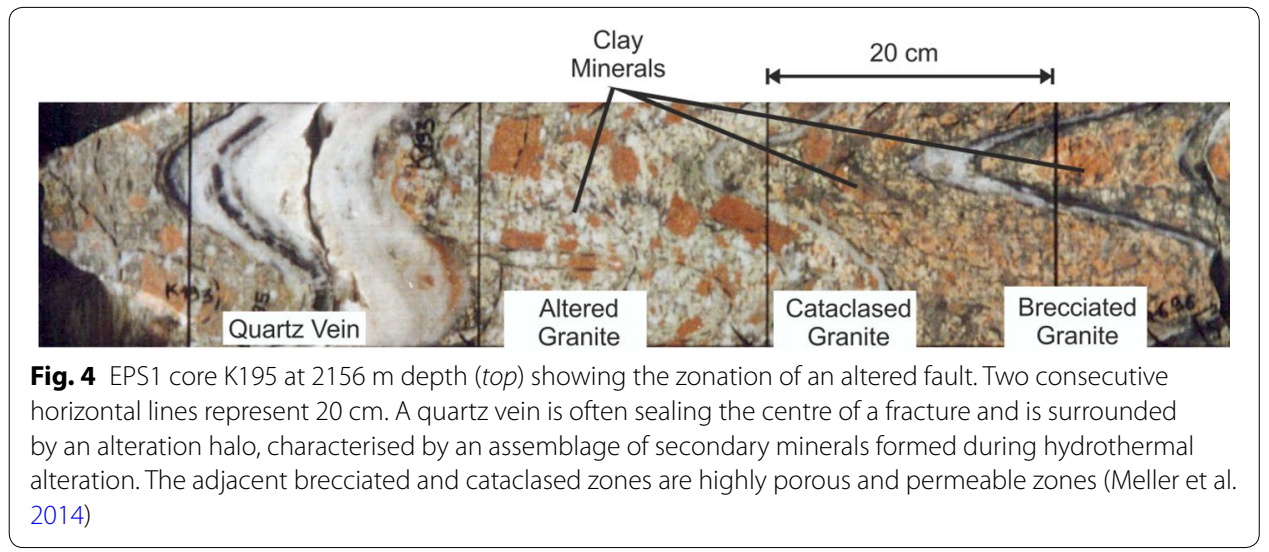

altered granite samples, for example, are reduced from about 55 to $40 \mathrm{GPa}$ compared to fresh rock samples (Valley and Evans 2007). Furthermore, a correlation between the occurrence of aseismic creep on fractures and the clay content (alteration grade) of fractures and between the cumulative occurrence of borehole breakouts and a high density of clay-filled fractures was observed. Moreover, the maximum magnitude of seismic events was observed to decrease with increasing clay content inside fractures. Evans et al. (2005) demonstrated that hydrothermally altered fractures can be enhanced best during stimulation. Thus, target candidates for geothermal exploration are fractures and 
faults, which are (1) optimally oriented in the ambient stress state, (2) critically stressed for shear reactivation, and (3) show increased fluid conductivities due to alteration processes.

\section{Selection criteria for a geothermal URL}

Considering the relevant observations at Soultz and the controllable and specific boundary conditions required for the planned CHFEs, a geothermal URL focusing on EGS should fulfil the following four selection criteria:

1. Complex geological boundary conditions are to be avoided. A rather homogenous crystalline matrix with a high density of connected and highly permeable natural fractures, i.e. a fracture network, provides optimal conditions for CHFE. In the engineered volume of Soultz with a vertical reservoir extension of about $3500 \mathrm{~m}$, maximum mean fracture length and damage zone size are of about 2700 and $60 \mathrm{~m}$, respectively (Massart et al. 2010). A realistic rock volume developed by an URL is $\ll 2 \cdot 10^{8} \mathrm{~m}^{3}$ (Table 1 ), which is much smaller than the defined EGS reservoir size suggested by Garnish (2002). Hence, we may consider fracture densities on the order of 2-3 $\mathrm{m}^{-1}$ with major fault and fracture zone lengths on the order of $<400-500 \mathrm{~m}$ (Sausse et al. 2010). The width of these zones (including damage and alteration zones) is estimated to be on the order of up to $<1-2 \mathrm{~m}$ (Massart et al. 2010). The lower limit of the overall hydraulic conductivity is set by the initial hydraulic conductivities of the Soultz reservoirs, which range from about $10^{-9}-10^{-8} \mathrm{~m} \mathrm{~s}^{-1}$ and the lower bound of matrix conductivity of about $>10^{-11} \mathrm{~m} \mathrm{~s}^{-1}$. Considering enhancement by stimulation (factor 10), we set this criterion to a hydraulic conductivity of $>10^{-7}-10^{-6} \mathrm{~m} \mathrm{~s}^{-1}$. This is in agreement with the permeability estimated by Kohl et al. (2000) for the fracture zones at Soultz.

2. Controllable hydraulic boundary conditions cause CHFEs to act on natural fractures or matrix, only. This is a pre-requisite for the validity of the CHFEs and the follow-up numerical models. Extensive drainage to surrounding known or unknown adits that may occur in areas of historic mining activities must be excluded.

3. Hydrothermal alteration products in the matrix and along the faults are to cover the illite to smectite range. Clay minerals are known to reduce the mechanical/frictional strength of fractures, i.e. the pressure required to cause shear during hydraulic stimulation. The contribution of mechanically induced rock alteration should be small, because the profound disintegration of large volumes of rock (e.g. grus) results in hydraulic conditions, which are no longer controllable (e.g. in terms of discrete hydraulic pathways, discrimination between matrix and fault, often no symmetry of the fault structure).

4. In order to carry out CHFEs, fractures that are favourably oriented for reactivation in the ambient stress field are an intrinsic pre-requisite of a geothermal URL. Since the stress field orientation across the European crystalline basement is highly variable, no specific stress field can be chosen, but a favourable reactivation potential has to be considered instead. Since the geothermal resources occur in normal or strike-slip regimes rather than thrust fault regimes, we may consider the latter as less favourable. Non-representative, atypical stress perturbation resulting from, e.g. the 
glacial rebound should be avoided. In mountain regions, significant perturbations of the regional stress field pattern by local topography need to be taken into account. To avoid such additional variation in the stress field that biases CHFEs with respect to reservoir condition, for the URL design, it is strived for a maximum variation in magnitude of the principal stress of $<10 \%$. Depending on the topography of a potential URL site, a minimum depth below terrain level has to be considered.

\section{URLs existing in the crystalline basement}

A number of URLs worldwide have been installed in crystalline basement rock (Fig. 5; Table 2). Except for the Josef URL, which comprises a number of different lithologies also of sedimentary origin, the host rocks exhibit only few lithological changes across the individual URLs. Host rocks range from gneissic (e.g. in the Mine Reiche Zeche) to granitic basement. The fractures at the Lindau Test Site and the Mine Reiche Zeche are commonly filled with ore minerals (Himmelsbach et al. 1998; Bayer 1998).

In the following section, suitability of the existing URLs for CHFEs will be discussed using the above four selection criteria. A compilation of the criteria for the URLs is given in Table 3. It should be noted that (1) the URL Lac du Bonnet is dismantled, (2) Onkalo is a site-specific URL for nuclear waste disposal and (3) the two URLs Sudbury and Sanford are not suitable for CHFE due to their sensitive instrumentation. All four URLs are, therefore, excluded from further consideration.

Criterion 1 is the crystalline lithology, including a well-connected fracture network and a high fracture transmissivity. Based on the minimum hydraulic conductivity range and the expected fracture apertures given above, for CHFEs, URLs with fracture transmissivities in the range of $>10^{-4} \mathrm{~m}^{2} \mathrm{~s}^{-1}$ may be take into account. In Europe, such condition are found in the Lindau Test Site and the Äspö Hard Rock Laboratory (HRL) and partly in the Mine Reiche Zeche (Table 2). Hydraulic testing revealed well-connected fracture networks at Äspö HRL and the Black Forest, in which the Lindau Test site is situated (Stanfors et al. 1999; Stober and Bucher 2014). At Grimsel, for instance, alpine tension fractures may have larger apertures and, hence, transmissivity, but are typically

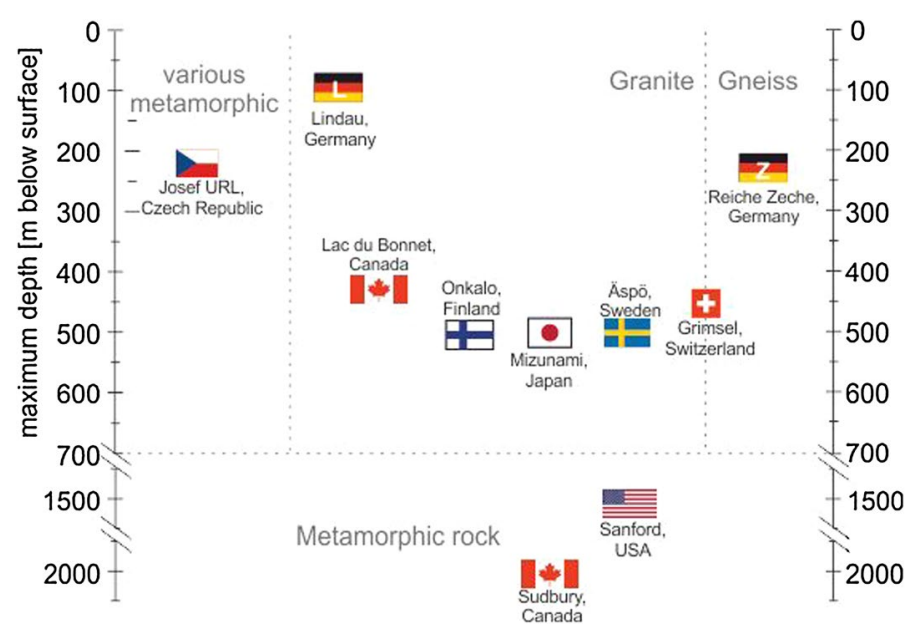

Fig. 5 Overview of the maximum depths of existing URLs in crystalline basement worldwide 
Table 2 Overview of general hydraulic conditions and secondary fracture fillings in selected URLs in the crystalline basement worldwide (e.g. Himmelsbach et al. 2003; Stanfors et al. 1999; Himmelsbach et al. 1998; Komulainen et al. 2014; Davison 1984; Kumazaki et al. 2003)

\begin{tabular}{|c|c|c|}
\hline Name & Hydraulic properties & Secondary minerals in fractures \\
\hline \multirow[t]{2}{*}{ Grimsel Test Site, Switzerland } & MHC: $10^{-12}-10^{-11} \mathrm{~m} \mathrm{~s}^{-1}$ & $\begin{array}{l}\text { Albite, epidote, muscovite, mica, } \\
\text { chlorite, calcite }\end{array}$ \\
\hline & FT: up to $10^{-10}-10^{-5} \mathrm{~m}^{2} \mathrm{~s}^{-1}$ & $\mathrm{CM}:<10 \%$ mainly illite \\
\hline \multirow[t]{3}{*}{$\begin{array}{l}\text { Äspö Hard Rock Laboratory, } \\
\text { Sweden }\end{array}$} & $\mathrm{MHC}:>10^{-12} \mathrm{~m} \mathrm{~s}^{-1}$ & $\begin{array}{l}\text { Chlorite, epidote, zoisite, albite, cal- } \\
\text { cite, fluorite, sericite, and zeolites, } \\
\text { hematite }\end{array}$ \\
\hline & FT: up to $>10^{-4} \mathrm{~m}^{2} \mathrm{~s}^{-1}$ & CM: illite, mixed-layer clay \\
\hline & Overall pumping rate: about $20 \mathrm{Ls}^{-1}$ & \\
\hline \multirow[t]{2}{*}{ Onkalo, Finland } & FT (depth $<85 \mathrm{~m}$ ): up to $>10^{-6} \mathrm{~m}^{2} \mathrm{~s}^{-1}$ & $\begin{array}{l}\text { Fe-sulphides, pyrrhotite, pyrite, and } \\
\text { calcite }\end{array}$ \\
\hline & $\begin{array}{l}\text { FT (depth }>85 \mathrm{~m} \text { ): up to }>10^{-7} \\
\mathrm{~m}^{2} \mathrm{~s}^{-1}\end{array}$ & CM: illite, smectite-group, kaolinite \\
\hline \multirow[t]{2}{*}{$\begin{array}{l}\text { AECL URL, Lac du Bonnet, } \\
\text { Canada }\end{array}$} & $\mathrm{MHC}:<10^{-11} \mathrm{~m} \mathrm{~s}^{-1}$ & $\begin{array}{l}\text { Chlorite, iron oxides, carbonates, } \\
\text { epidote }\end{array}$ \\
\hline & FT: up to $>10^{-3} \mathrm{~m}^{2} \mathrm{~s}^{-1}$ & CM: present (type N/A) \\
\hline \multirow[t]{2}{*}{ Mizunami URL, Japan } & $\mathrm{HC}$ (fresh Toki granite): $>10^{-7} \mathrm{~m} \mathrm{~s}^{-1}$ & $\begin{array}{l}\text { Quartz, plagioclase, K-feldspar and } \\
\text { biotite, iron oxides, chlorite, calcite }\end{array}$ \\
\hline & HC (altered Toki granite): $>10^{-8} \mathrm{~m} \mathrm{~s}^{-1}$ & CM: kaolinite, montmorillomite \\
\hline \multirow[t]{2}{*}{ Josef URL, Czech Republic } & $\mathrm{HC}$ (overall): $2-5 \cdot 10^{-9} \mathrm{~m} \mathrm{~s}^{-1}$ & Ore (gold, ...), quartz, calcite, barite \\
\hline & & $C M: n / a$ \\
\hline \multirow{2}{*}{$\begin{array}{l}\text { Mine Reiche Zeche, Freiberg, } \\
\text { Germany }\end{array}$} & $\mathrm{MHC}:<10^{-12} \mathrm{~m} \mathrm{~s}^{-1}$ & \multirow{2}{*}{$\begin{array}{l}\text { Ore: sulphides, quartz, fluorite, } \\
\text { sulphates, barite, feldspars, pyrite } \\
\text { CM: n/a }\end{array}$} \\
\hline & FT: up to $10^{-8}-10^{-4} \mathrm{~m}^{2} \mathrm{~s}^{-1}$ & \\
\hline \multirow[t]{3}{*}{$\begin{array}{l}\text { Lindau test site, Black Forest, } \\
\text { Germany }\end{array}$} & $\begin{array}{l}\mathrm{HC} \text { (fractured ore dike): } 5 \cdot 10^{-6}- \\
10^{-4} \mathrm{~m} \mathrm{~s}^{-1}\end{array}$ & Quartz, fluorite, barite, ore \\
\hline & $\begin{array}{l}\mathrm{HC} \text { (fractured granite): } 5 \cdot 10^{-10} \\
10^{-8} \mathrm{~m} \mathrm{~s}^{-1}\end{array}$ & \multirow[t]{2}{*}{ CM: kaolinite } \\
\hline & FT: up to $>10^{-6}-5 \cdot 10^{-4} \mathrm{~m}^{2} \mathrm{~s}^{-1}$ & \\
\hline
\end{tabular}

$H C$ hydraulic conductivity, $M H C$ matrix HC, FT fracture transmissivity, CM clay minerals

Table 3 Criteria match of existing URLs in the crystalline basement worldwide

\begin{tabular}{|c|c|c|c|c|c|c|}
\hline \multirow[t]{2}{*}{ Name } & \multicolumn{2}{|l|}{ Criterion 1: } & \multirow{2}{*}{$\begin{array}{l}\text { Criterion 2: } \\
\text { Controllable } \\
\text { hydraulic } \\
\text { boundary } \\
\text { condition }\end{array}$} & \multirow{2}{*}{$\begin{array}{l}\text { Criterion 3: } \\
\text { Comparable } \\
\text { alteration } \\
\text { (clay } \\
\text { minerals) }\end{array}$} & \multicolumn{2}{|l|}{ Criterion 4: } \\
\hline & $\begin{array}{l}\text { Fractured } \\
\text { and rather } \\
\text { homoge- } \\
\text { nous crystal- } \\
\text { line matrix }\end{array}$ & $\begin{array}{l}\text { Fracture } \\
\text { transmissivity }> \\
10^{-4} \mathrm{~m}^{2} \mathrm{~s}^{-1}\end{array}$ & & & $\begin{array}{l}\text { Suitable } \\
\text { stress } \\
\text { condition }\end{array}$ & $\begin{array}{l}\text { Sufficient } \\
\text { overburden }\end{array}$ \\
\hline Grimsel Test Site & Yes & No & Partly & No & No & Yes \\
\hline $\begin{array}{l}\text { Äspö Hard Rock } \\
\text { Laboratory }\end{array}$ & Yes & Yes & Yes & Yes & Limit & Yes \\
\hline Mizunami URL & Yes & Limit & Yes & No & No & Yes \\
\hline Josef URL & No & No & Yes & No & Yes & Limit \\
\hline $\begin{array}{l}\text { Mine Reiche } \\
\text { Zeche }\end{array}$ & Yes & Limit & No & Yes & Yes & Limit \\
\hline Lindau Test Site & Yes & Yes & Yes & N/A (No) & Yes & No \\
\hline
\end{tabular}

Limit at the limit of the criteria. Partly the hydraulic boundary conditions are generally controllable, but due to storage lakes above the URL, special equipment may be needed 
short or poorly connected (Himmelsbach et al. 2003). Geothermal energy development activities at Josef URL and Grimsel Test Site focus on HDR or multi-frac technology aiming at engineering naturally impermeable crystalline rock. These approaches represent the opposite end-member of EGS technology are complementary to CHFE.

Criterion 2, controllable hydraulic boundary conditions, further reduces the number of URLs suitable for CHFEs. At the Mine Reiche Zeche, 800 years of continuous mining activities resulted in a dense network of adits causing complex and non-controllable boundary conditions for CHFEs. It should be mentioned that topography-driven fluid circulation at the Lindau Test Site and influence from the Baltic Sea at the Äspö HRL lead to a certain complexity of natural boundary conditions. In the latter case, this mainly concerns the chemical composition of the fluid.

Criterion 3, hydrothermal alteration in the illite-smectite range, is fulfilled at the Äspö HRL. At the Lindau Test Site, only kaolinite is found as clay mineral. Interestingly, clay minerals occur preferably in NW-SE striking fractures (Himmelsbach, pers. comm.). However, hydrothermal alteration has not been studied in detail at the Lindau Test Site. In the Black Forest, alteration often resembles clay mineral assemblage at the Soultz site. For example, 60-90 wt\% of illite, smectite, and chlorite are observed in altered granitic rocks of the southern Black Forest batholith (Brockamp et al. 2015).

Criterion 4 refers to suitable regional and homogenous stress conditions across the URL. Near the Äspö HRL, various stress measurements were made in the tunnel and nearby wells using different measurement techniques. The results are summarised, e.g. by Hakami (2003). Large scattering of $S_{\mathrm{Hmax}}$ orientation and principal stress magnitudes is observed. The scattering occurs across the entire depth range down to $800 \mathrm{~m}$ and appears to be independent of the measurement technique. Thus, regional and in situ stress states are not fully constrained. However, a mean $S_{\mathrm{Hmax}}$ orientation of $\mathrm{N} 119^{\circ} \mathrm{E}-$ $\mathrm{N} 138^{\circ} \mathrm{E}$ is observed in the SE Sweden area (Stephansson et al. 1991) and linear stressdepth relations predict a transitional stress state between thrust and strike-slip faulting with $S_{\mathrm{v}} \approx S_{\mathrm{hmin}} \ll S_{\mathrm{Hmax}}$ (Hakami and Min 2009; Klee and Rummel 2002). Hence, fault and fracture reactivation may occur on three differently oriented failure planes. If $S_{\mathrm{hmin}}$ is the smallest principal stress magnitude, a strike-slip faulting regime is supposed to reactivate vertical structures at two conjugated $30^{\circ}$ angles around $S_{\mathrm{Hmax}}$. If $\mathrm{S}_{\mathrm{v}}$ is smallest, a thrust faulting regime is expected to reactivate sub-horizontal structures with a dip of about $30^{\circ}$. All three fracture orientations are predominantly observed at Äspö (Rehn et al. 1997). Favourably oriented and critically stressed structures additionally show increased fracture conductivities. In the borehole KAS06, for example, water-conducting fractures strike around $132^{\circ}$ and are aligned almost parallel to $S_{\mathrm{Hmax}}$ (Sehlstedt and Strahle 1991).

At the Lindau Test Site, application of a slip- and dilation tendency analysis on the resulting fault pattern reveals the high reactivation potentials for the $\mathrm{N}-\mathrm{S}$ striking ore dike as strike-slip fault and for NW-SE striking structures as normal faults within the ambient stress field (see below). However, strong perturbation of the stress field inside the existing is expected due to a steep slope topography in combination with a low overburden of only $90 \mathrm{~m}$. This is considered insufficient for providing rather topographyindependent stress conditions in the tunnel. 
It can be concluded that the Äspö HRL and Lindau Test Site approximate best criteria for CHFEs. While at the Lindau Test Site insufficient overburden represents a criteria of exclusion for the existing design of the tunnel, at Äspö HRL the general stress situation is unsatisfactorily described and furthermore includes most likely thrust faulting. Both URLs may be used in a qualified sense for complementary experiments. In agreement with these findings and the criteria for GeoLaB, we have carried out further studies in the southern Black Forest for the following reasons:

1) The basement outcropping in the Black Forest represents to a large extent the lithology of the geothermal host rock in the URG.

2) Appropriate hydrothermal alteration is widely observed in the Black Forest (Brockamp et al. 2015).

3) Extended fracture networks are indicated (Stober and Bucher 2014).

4) Apart from overburden the Lindau Test Site indicates the general suitability of the southern Black Forest. Hydraulic condition fixed in criterion 1 are achieved (Himmelsbach et al. 1998) and the regional stress field represents or at least approximates conditions of major EGS projects in the URG.

\section{Geology and hydrogeology of the black forest Geology of the Black Forest}

From $\mathrm{N}$ to $\mathrm{S}$, the Black Forest is subdivided into four zones: the Baden-Baden Zone (BBZ), Central Black Forest Gneiss (CSGC), and Southern Black Forest Granite Complexes (SSGC) that are separated by the Badenweiler-Lenzkirch Zone (BLZ) (Fig. 6). The low-grade metamorphic rocks of BBZ comprise schists, meta-greywackes, and marbles and are separated from the medium to high-grade metamorphic rocks of the CSGC by a major NE-SW striking dextral-transpressive ductile shear zone. Shearing occurred between $335 \mathrm{Ma}$ and the intrusion of an about $325 \mathrm{Ma}$ old biotite-muscovite granite that was cataclastically deformed during sinistral brittle reactivation (Eisbacher et al. 1989; Hess et al. 2000; Kober et al. 2004; Wickert et al. 1990). The CSGC essentially consists of migmatitic and, locally, mylonitic biotite-plagioclase-gneisses hosting irregularly shaped and sized bodies of amphibolites and eclogites, serpentinised peridotites, and granulites (Kalt and Altherr 1996; Marschall et al. 2003). It was intruded at about 330-325 Ma by batholiths of different size and numerous granitic to porphyritic dykes (Hess et al. 2000). The BLZ is an about $5-10 \mathrm{~km}$ wide metasedimentary-metavolanic succession that includes low-grade to non-metamorphic Ordovician to late Carboniferous sedimentary and volcanic rocks (e.g. Krecher and Behrmann 2007). It was overthrust by the CSGC along the dextral transpressive $\mathrm{N}$ - to NW-dipping, mylonitic-cataclastic Todtnau thrust (Krohe and Eisbacher 1988; Eisbacher et al. 1989). The southern boundary of BLZ is a WNW-trending shear zone (e.g. Krecher and Behrmann 2007). The SSGC was intruded by the large South Black Forest Batholith between 334 and 328 Ma (Schaltegger 2000; Todt 1976).

Major brittle, commonly mineralised fault zones are observed in abandoned mines (e.g. Werner and Dennert 2004) and quarries and-on a regional scale-at the basement-cover interfaces. During late Variscan times, i.e. from about 310 to $330 \mathrm{Ma}$, deep and high-level crystalline basement rocks cooled to below $300{ }^{\circ} \mathrm{C}$ in the Moldanubian 


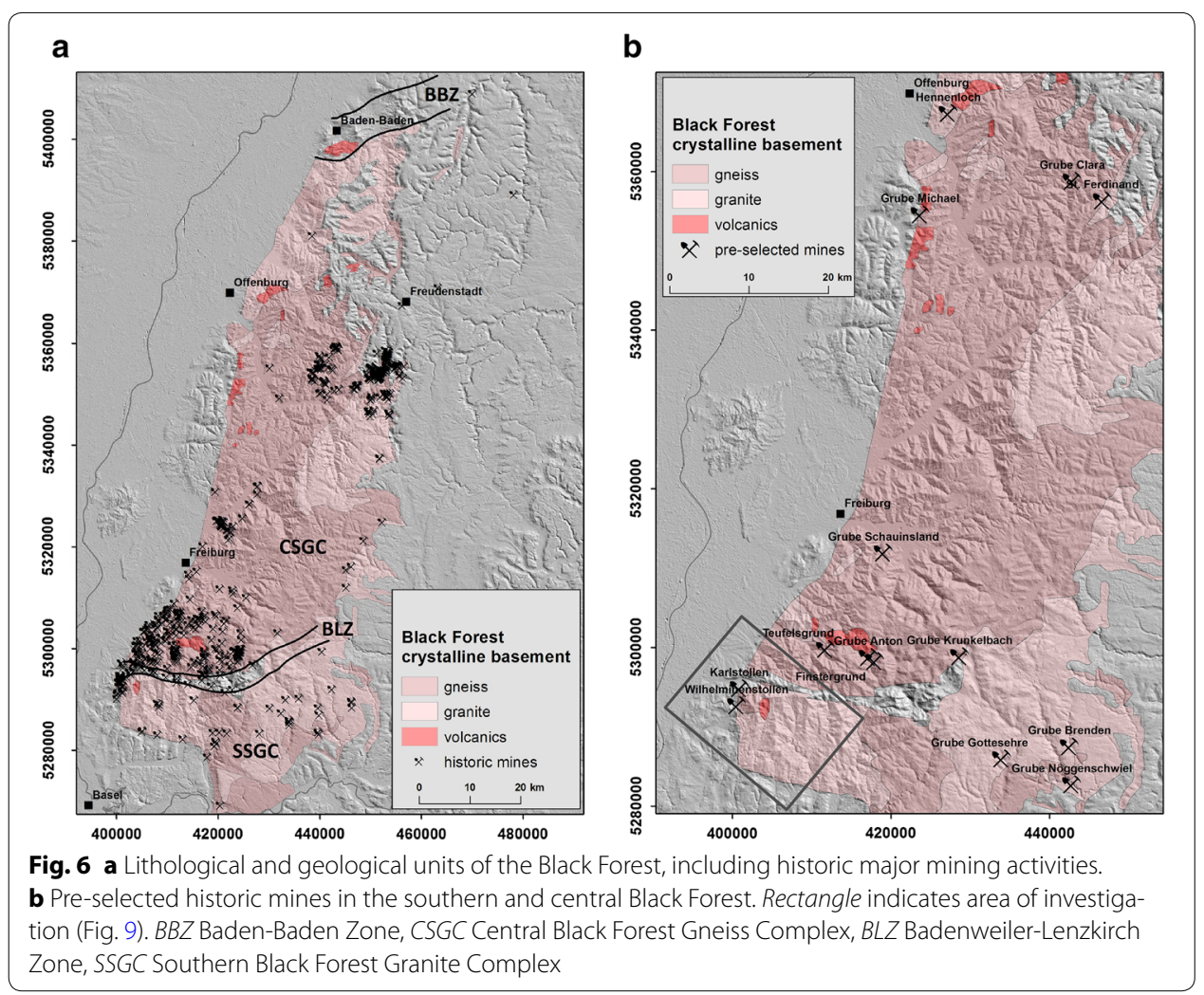

zone of the Black Forest and, hence, reached upper crustal brittle levels, with retrograde mylonitic shear zones being transformed into cataclastic fault zones (e.g. Eisbacher et al. 1989; Grimmer et al. 2016).

The crystalline basement rocks of the Black Forest display important late- to postVariscan alteration and mineralisation features (e.g. Simon 1990; Zuther and Brockamp 1988). The Southern Black Forest batholith has significantly reduced $\partial^{18} \mathrm{O}$-values compared to its magmatic equilibrium values and to the $325 \mathrm{Ma}$ old granites of the Northern Black Forest Batholith (Hess et al. 2000; Schaltegger 2000; Simon 1990; Hoefs and Emmermann 1983). On the regional scale, the directions, timing, and relative proportions of descending low $\partial^{18} \mathrm{O}$ meteoric paleofluids versus ascending or recycled and internally buffered high $\partial^{18} \mathrm{O}$ paleofluids are largely unknown. On the local scale, detailed geochemical studies of post-Variscan mineralised veins indicate a mixture of ascending and descending fluids during mineral formation in fault zones (e.g. Bons et al. 2014). Radiometric dating of minerals originating from hydrothermal alteration of crystalline basement rocks and Permo-Triassic cover rock successions as well as of minerals originating from fault-related, mineralised veins reveal multiple and complex postVariscan phases of pervasive and localised fluid-rock interactions (Brockamp et al. 2015; Zuther and Brockamp 1988; Glodny and Grauert 2009).

\section{Hydrogeology of the Black Forest}

Features of brittle deformation, such as faults and joints, are the principal fluid-conducting structures in crystalline basement rock. In the Black Forest and URG area, hydraulic 
tests in boreholes down to $5 \mathrm{~km}$ depth revealed hydraulic conductivity values that range over nine orders of magnitude from $10^{-13}$ to $10^{-4} \mathrm{~m} \mathrm{~s}^{-1}$ with a $\log$ mean of $7 \cdot 10^{-6} \mathrm{~m} \mathrm{~s}^{-1}$ over 175 tests (Stober and Bucher 2007). The large variance observed at shallow depth decreases rapidly to a range between $10^{-8}$ and $10^{-6} \mathrm{~m} \mathrm{~s}^{-1}$ at about $1 \mathrm{~km}$ depth. A characteristic value of $10^{-8} \mathrm{~m} \mathrm{~s}^{-1}$ is observed at $4 \mathrm{~km}$ depth. This decrease appears to be pronounced in gneissic basement (Stober 1995). Thus, mean hydraulic conductivities of $1 \cdot 10^{-6} \mathrm{~m} \mathrm{~s}^{-1}$ in fractured granite are generally higher than in fractured gneiss $\left(5 \cdot 10^{-8} \mathrm{~m} \mathrm{~s}^{-1}\right.$; Fig. 7).

Several hydraulic test data indicated the influence of faults or fault zones acting as distant hydraulic boundaries. Hydraulic conductivities were lower than the values of the undisturbed crystalline basement, retrieved from the radial flow period (Stober and Bucher 2014). This permeability contrast was attributed to low permeabilities within the core of the fault. Investigation of water table fluctuations due to earth tides, of drawdown data from long-term pumping tests, and of hydrochemical and thermal data from long-term observations of deep circulating systems (natural thermal springs) shows that the open water-conducting fractures and pore spaces form an interconnected network in the crystalline basement with characteristic hydraulic properties (e.g. Stober and Bucher 2014). Thus, the crystalline basement can be regarded as an aquifer in hydraulic terms.

Bucher and Stober (2000) and Pearson et al. (1991) summarised the hydrochemical characterisation of crystalline fluids in the Black Forest and adjacent areas. Three major types of groundwater can be distinguished (Fig. 8). Besides near-surface fresh type 1 water (Fig. 8a), $\mathrm{CO}_{2}$-rich mineral type 2 water (Fig. 8 b) is predominantly occurring in the central Black Forest (e.g. Bad Peterstal, Bad Griesbach, Bad Teinach), whereas saline thermal type 3 water (Fig. 8c) is found mostly in the northern and southern Black Forest (e.g. Wildbad, Bad Liebenzell, Baden-Baden, Bad Säckingen, Zurzach). The latter results from the mixing of surface freshwater, saltwater, and a water-rock reaction component from an up to about 3-5 km deep reservoir. $\mathrm{CO}_{2}$-rich mineral water in the central Black

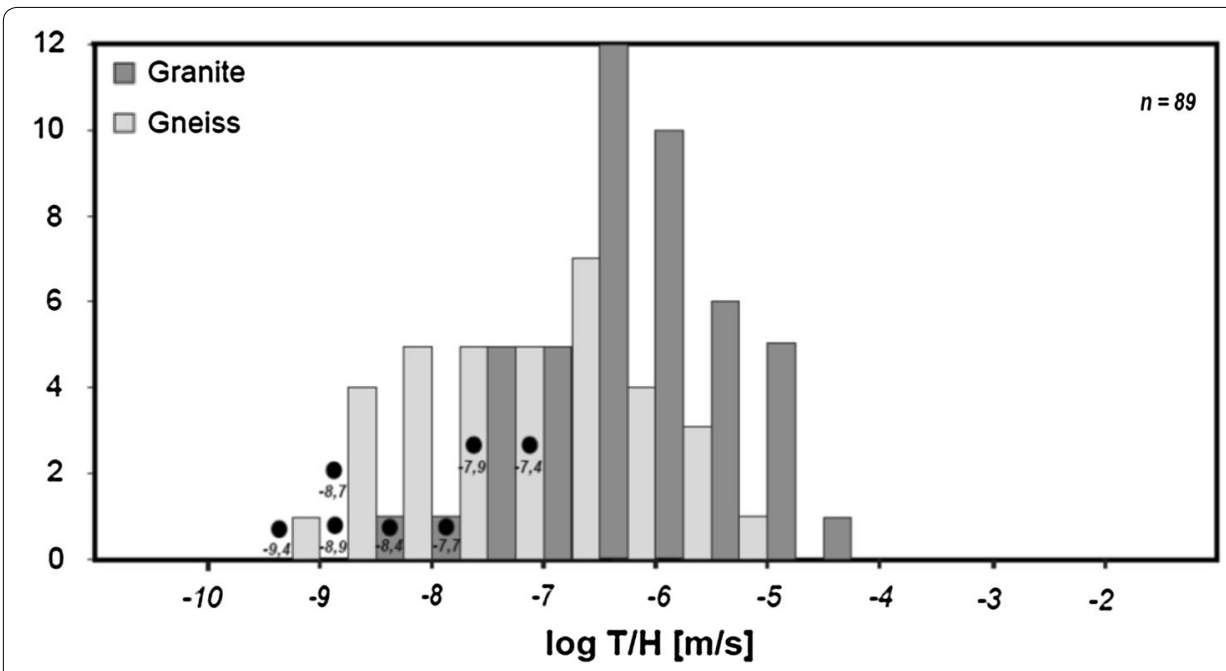

Fig. 7 Hydraulic conductivities from 89 hydraulic tests in the granitic and gneissic basement of the Black Forest, modified after Stober (1995). Wells with mixed lithology, granite, and gneiss, are not considered. Black dots additional hydraulic conductivities of deep wells in the URG for comparison 


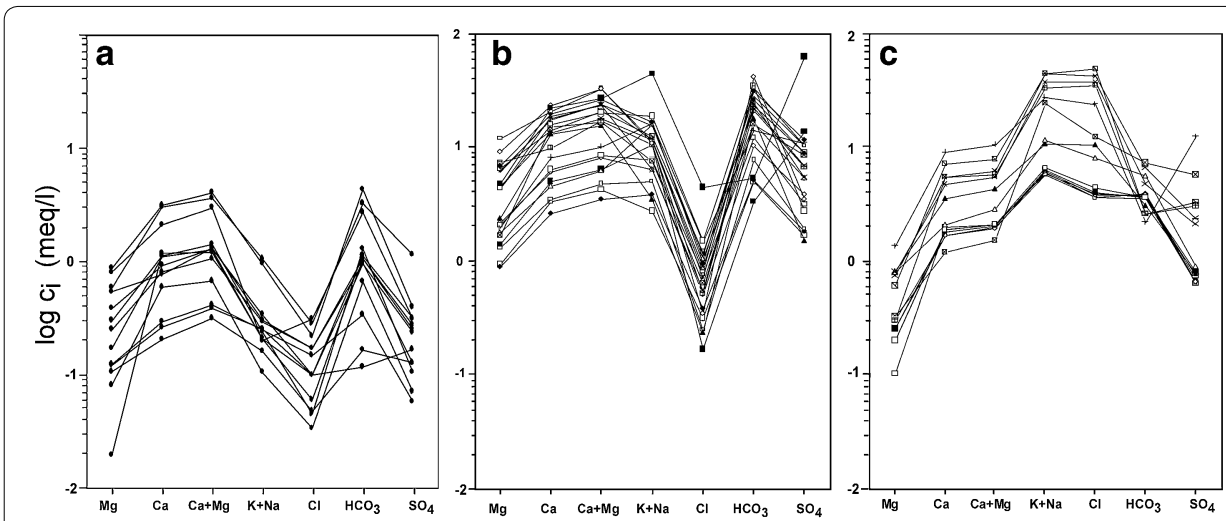

Fig. 8 Comparison of near-surface $(\mathbf{a})$, naturally occurring $\mathrm{CO}_{2}$-rich mineral $(\mathbf{b})$, and thermal waters $(\mathbf{c})$ in the Black Forest, modified after Stober and Bucher (2000)

Forest is of low salinity and its chemical composition results from the reaction of $\mathrm{CO}_{2}$ rich water with the crystalline rock matrix at relatively shallow depth $(<500 \mathrm{~m})$ exclusively. The main water components are $\mathrm{Ca}, \mathrm{Na}$, and $\mathrm{HCO}_{3}$ (Fig. 8b). In types 1 and 2, the total of dissolved solids (TDS) is enhanced. The type 1 groundwater resembles main water components of type 2, but has a significantly lower TDS and is poor in $\mathrm{CO}_{2}$. It develops due to interaction of rainwater with crystalline basement rocks. Thus, a distinct stratification in hydrochemistry with increasing depth results: TDS increases and the water type changes from $\mathrm{Ca}-(\mathrm{Na})-\mathrm{HCO}_{3}$ to $\mathrm{Na}-\mathrm{Cl}$ rich waters.

Topography-driven deep circulation systems in the Black Forest occur in granites. Highly permeable fracture and fault zones in granites are used as ascent channels and flow paths by deep hot saline crystalline basement waters. Although spatially closely associated, the saline deep waters and the $\mathrm{CO}_{2}$-rich mineral waters are hydraulically and chemically unconnected (e.g. Bucher and Stober 2000).

\section{Preliminary criteria validation in the southern Black Forest}

An exploration concept has been established to pre-characterise a suitable site for Geo$\mathrm{LaB}$ in the Black Forest from the surface. It aims at indicating the subsurface condition that are relevant to CHFE in the run-up of large exploration including exploration wells. The concept is based on the recommendations for characterising, modelling, and monitoring fractured rock sites of the National Academies of Sciences (2015). It includes geometric characterisation using lineament mapping techniques, geomagnetic, geoelectric, georadar measurements, geological mapping. In the absence of boreholes, no geophysical logging or hydraulic testing is envisaged at this stage. In addition, a hydrochemical exploration is included. The concept was applied and tested along the Wilhelminenstollen, an exploration tunnel selected from about 700 abandoned mines in the Black Forest according to the selection criteria above. The study is to be updated upon the continuation of the project.

\section{Structural setting of the southern Black Forest}

In addition to the geological and structural mappings summarised in the Geological Map of Baden-Württemberg (1:50,000, LGRB, 2015), lineaments of the southern Black forest 
were mapped using high-resolution digital elevation models with up to $5 \times 5 \mathrm{~m}$ resolution. Compared to earlier studies (Franzke et al. 2003), a higher lineament density in the southern Black Forest and predominant (S)SW, (W)NW, and N trending strike directions are observed (Fig. 9). These directions are also observed in the geothermal reservoir at Riehen and Basel in the URG (Meixner et al. 2016). From stress measurements in the entire Black Forest a strike-slip regime with a $S_{\mathrm{Hmax}}$ orientation of $\mathrm{N} 140^{\circ} \mathrm{E} \pm 10^{\circ}$ was obtained.

The resulting fault and stress field models were used for slip- and dilation tendency analyses (Fig. 9). The reactivation potential reveals two local maxima. Faults that strike about $\mathrm{N} 110^{\circ} \mathrm{E}$ and $\mathrm{N} 170^{\circ} \mathrm{E}$ are prone for shear reactivation as dextral and sinistral strikeslip faults, respectively. Dilation is most likely to occur in directions parallel to $S_{\mathrm{Hmax}}$. Highest lineament density is observed for the $\mathrm{N} 110^{\circ} \mathrm{E}$ strike direction that exhibits both slip and dilation tendency maxima.

\section{Possible sites for GeoLaB in the southern Black Forest}

Generally, there are two main approaches to constructing a geothermal URL in the southern Black Forest: using and connecting to an existing tunnel or mine or constructing a new tunnel. Existing tunnels or mines may provide the necessary infrastructure, e.g. road access to the location. Moreover, rock properties, the fracture network, and hydraulic conditions can be investigated in situ before major investments are committed.

Of the more than 700 historic mines in the Black Forest (Steen 2004; Werner and Dennert 2004), 15 sites were pre-selected according to the size and accessibility of the tunnel (Fig. 6). To evaluate their suitability for CHFE, the lithology and overburden were analysed from literature. Fracture transmissivity can only be inferred occasionally from the water budget in the mines. Commonly, information on hydrothermal alteration is lacking. Regional stress conditions in the Black Forest are generally suitable for CHFEs. Controllable hydraulic boundary conditions is one of the most important criteria for CHFEs in pre-existing tunnel systems.

To avoid complex and unknown tunnel systems, we selected a single exploration tunnel, the Wilhelminenstollen near Badenweiler, as potential GeoLaB site. Wilheminenstollen is documented well and led to no further mining activity. Furthermore, it fulfils a number of other criteria such as lithology, open fracture zones, and clay minerals comparable to the Soultz site. For these reasons, it was chosen as a case study site to test an assessment procedure for a geothermal URL in crystalline basement rock. Geological, hydrogeological, and geophysical methods have been applied to indicate the suitability of the Wilhelminenstollen for an URL.

\section{Geological setting at the Wilhelminenstollen}

The $521 \mathrm{~m}$ long, E-W trending Wilhelminenstollen is located SE of Badenweiler in the SSGC (Fig. 10). Together with the earlier constructed Sehringer Stollen, which is located approximately $50 \mathrm{~m}$ higher, it was installed around 1920 at Sehringen to explore the mineralised veins in the Blauen granite and was abandoned a few years later. The tunnel entrance is located immediately east of the Black Forest escarpment fault. Today, about $37,500 \mathrm{~m}^{3}$ of drinking water per year are collected from open fractures in the tunnel. 

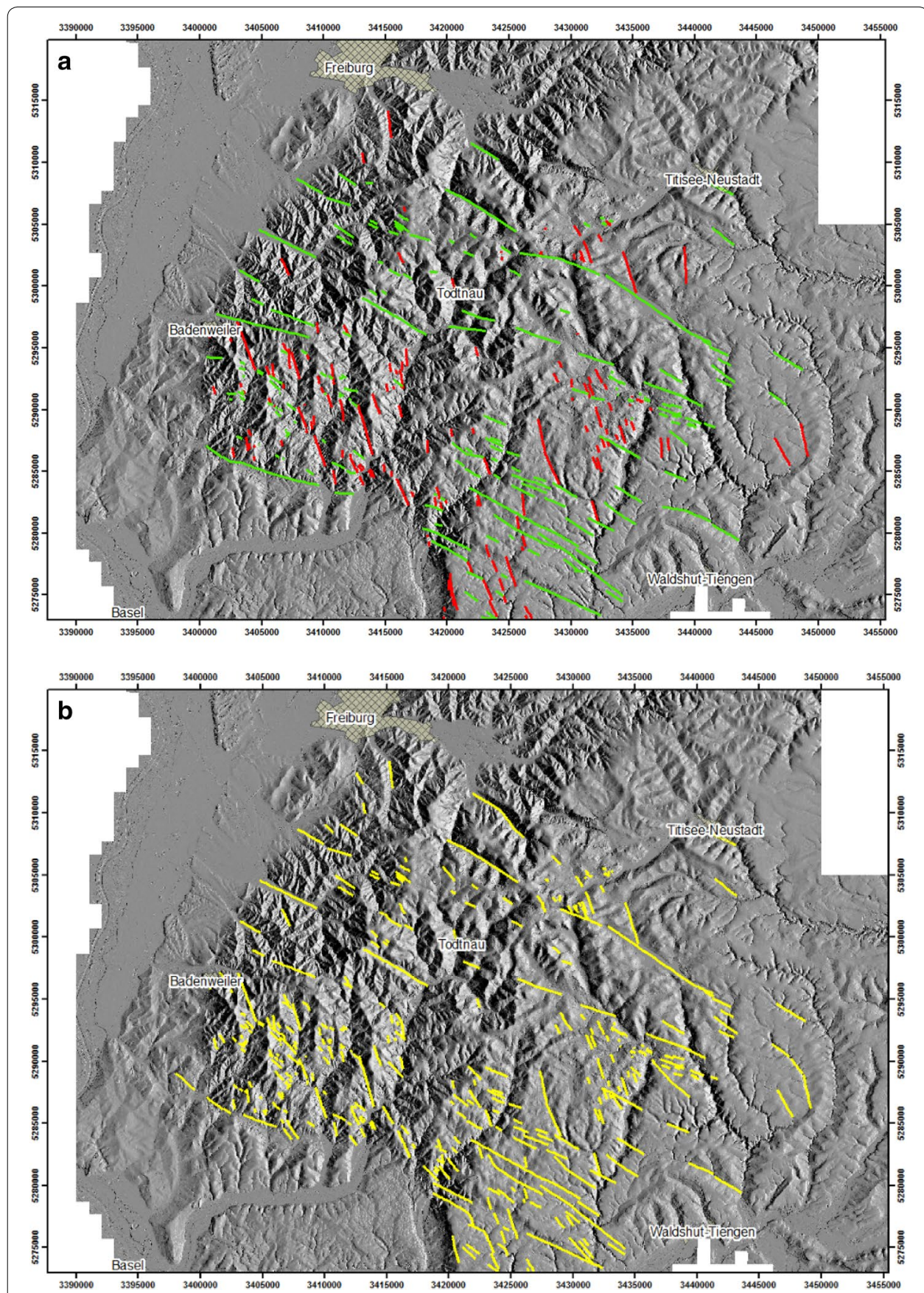

Fig. 9 Maximum tendencies for slip with $T_{S}>0.6(\mathbf{a})$ and dilation with $T_{D}>0.7(\mathbf{b})$ of the predominant fault settings in the southern Black Forest obtained from lineament analyses of digital elevation models (LIDARDEM5). Red/green sinistral/dextral reactivation

Structurally, three major features laterally frame the study area. To the north, segmented E-W striking normal faults separate the SSGC from the Badenweiler-LenzkirchZone. East of the Mt. Blauen, the N to NNW striking Schweighof fault zone and the N-S trending graben structure of Marzell juxtapose the SSGC granites against Permian volcanics. To the west, the NNE striking Black Forest escarpment fault marks the structural 


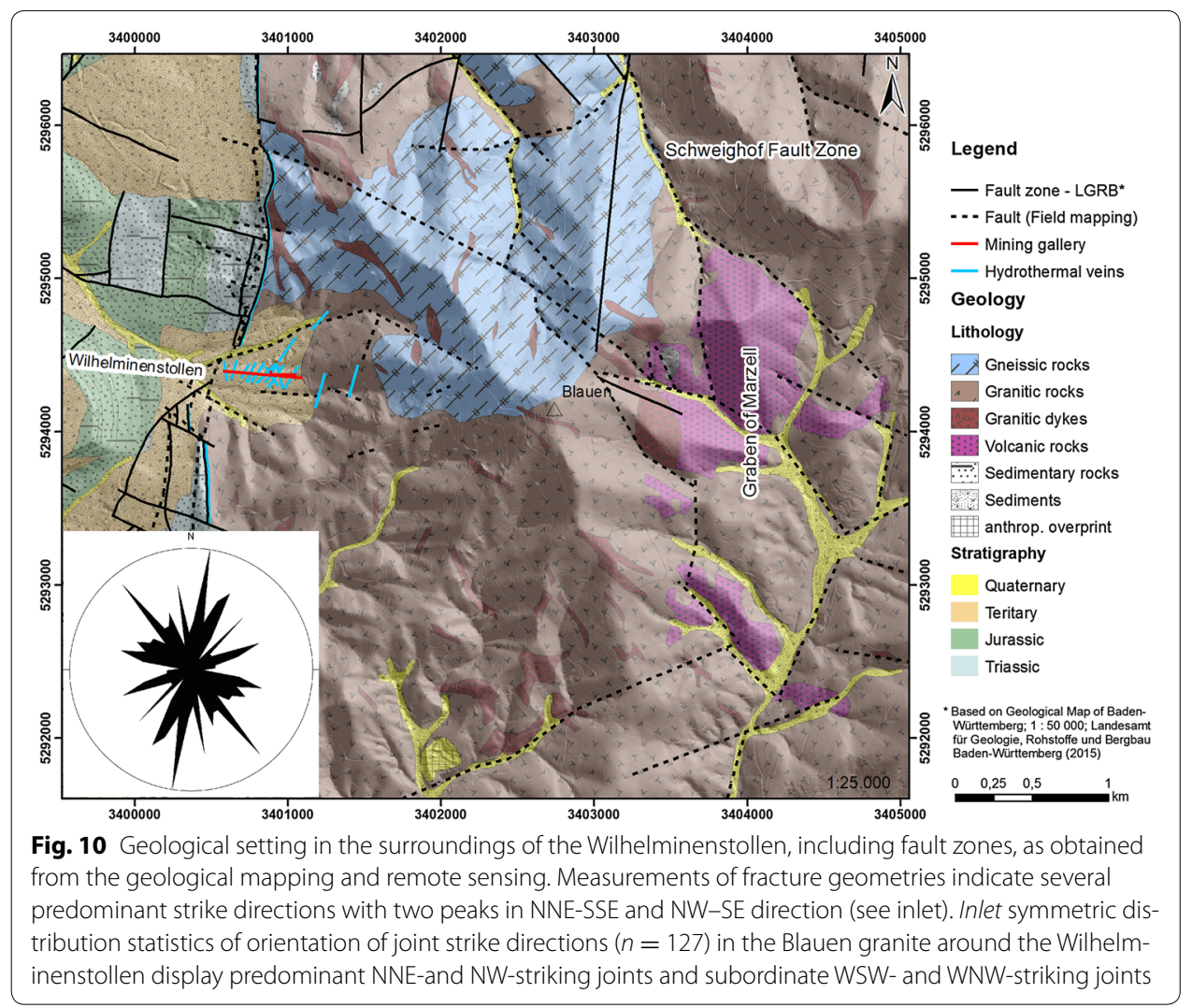

border between the exposed crystalline basement rocks and the Mesozoic cover. It is segmented by NE and SE striking transfer faults which accommodate an E-W extension in the form of oblique normal faults with a sinistral and dextral a strike-slip component. NW to NNW and NE to SW trending faults resulted from post-orogenic extensional tectonics during Variscan orogeny, but show polyphase reactivations in the Mesozoic and Cenozoic (Huber and Huber-Aleffi 1984; Schumacher 2002).

Two different petrologic units, the Blauen granite and the Wiese-Wehra formation, are exposed in the study area. The medium- to fine-grained biotite-type Blauen granite was linked to the about 328-333 Ma old Malsburg granite (Sawatzki et al. 2003). The second petrologic unit mainly consists of gneissic rocks commonly designated as diatexites of the Wiese-Wehra formation.

NNE striking faults and fracture zones are often filled by cataclastic material or by hydrothermally and mechanically altered secondary minerals, such as hematite, Fehydroxide, clay minerals, barite, or quartz. Especially the NNE striking escarpment fault zone is accompanied by several hydrothermal veins. These deposits are fault- and fracture-hosted veins and seem to be directly linked to brittle deformation processes. Formation ages indicate hydrothermal activity in the Black Forest area since Variscan times, with a peak in the Jurassic (Bons et al. 2014). But NNE alignment of the veins close to the escarpment fault may also indicate correlation of Cenozoic rifting and origin of hydrothermal circulation along this fault. Breccia textures of the veins also reflect repeated cycles of fault reactivation and mineral precipitation. The veins almost constantly 
strike NNE-SSW with varying dip angles between about $45-80^{\circ}$. Interestingly, most of the veins dip to the E, opposite to the escarpment fault, which was active during URG formation. This may indicate that hydrothermal circulation and mineral precipitation took place at both conjugated shear angles during active normal faulting. The epigenetic ore deposits in the study area mainly consist of lead-bearing quartz-barite veins and were formed by mixture of fluids of different origin (Bons et al. 2014; Kneer 2006). The distribution of the inflow of water into the tunnel and the high Ba concentration of $442.3 \mu \mathrm{g} \mathrm{L}{ }^{-1}$ indicate a clear link between the barite-filled fractures and fluid pathways.

$\mathrm{X}$-ray diffraction (XRD) analyses of powders of fracture fillings from the Black Forest escarpment fault and a fracture in the front part of the Wilhelminenstollen revealed an asymmetric peak at $2 \theta$ (CuKalpha) $=10 \AA$ characterised by tailing towards lower $2 \theta$ values. This indicates the presence of mica/illite together with an illite-smectite interstratification in the alteration products. Ethylene glycol treatment confirmed the presence of the swellable interstratification. No indication of free smectite was found.

\section{Fault characterisation}

Due to the lack of geological outcrops in the southern Black Forest, the identification of faults from the surface requires geophysical measurements. In a first reconnaissance study, the faults and veins near the Wilhelminenstollen were identified successfully using electric resistivity measurements. Geo-electric measurements were conducted using a 4-point Light High Power with 60 electrodes (LMG) and Geo-Test (Geophysik Dr. Rauen). Dipole-dipole and pole-dipole geometries with an electrode offset of 0.5-45 m were used. Geographic coordinates were acquired using a Trimble R4 with Sapos-correction. In addition, geomagnetic and georadar data have been acquired (not shown). Compared to geoelectric measurements, they are less conclusive.

First, a calibration profile was measured across the Black Forest escarpment fault exposed along the road to Sehringen (CP, Fig. 11). The fault zone dips towards WNW with about $60^{\circ}$. As indicated by the geological map, the exact location and the number of branches of the targeted fault zone are a matter of discussion. Both, electric resistivity and phase shift indicate an anomaly between profile meters 5 and 10 (Fig. 12). The anomalies are observed to an off-set of $>10 \mathrm{~m}$ corresponding to a depth of approximately $5 \mathrm{~m}$. There is some minor indication of a smaller anomaly around profile meters 20 in the apparent resistivity.

Hydrothermal veins partly filled with quartz and $\mathrm{Mg}$-, Pb-ore minerals and barite within the Wilhelminenstollen mostly dip to the ESE or ENE with about $45-60{ }^{\circ} \mathrm{C}$. Here, they are mapped from the surface in variable quality using electric resistivity (Fig. 13). Correlation of the near-surface anomalies and the hydrothermal veins in the tunnel is possible when considering an E-W offset due to the dip of the structures. Two low resistivity anomalies in the western part of $\mathrm{P} 4$ coincide well with the shifted position of veins in the tunnel. These two veins are Pb-bearing structures. The vein at profile meter 102 is not detected by resistivity measurements. This may be attributed to the fact that this vein is filled by quartz and Mg only. The easternmost veins at the edge of the profile (profile meters 149.5 and 151.5) are not covered by the profile. 


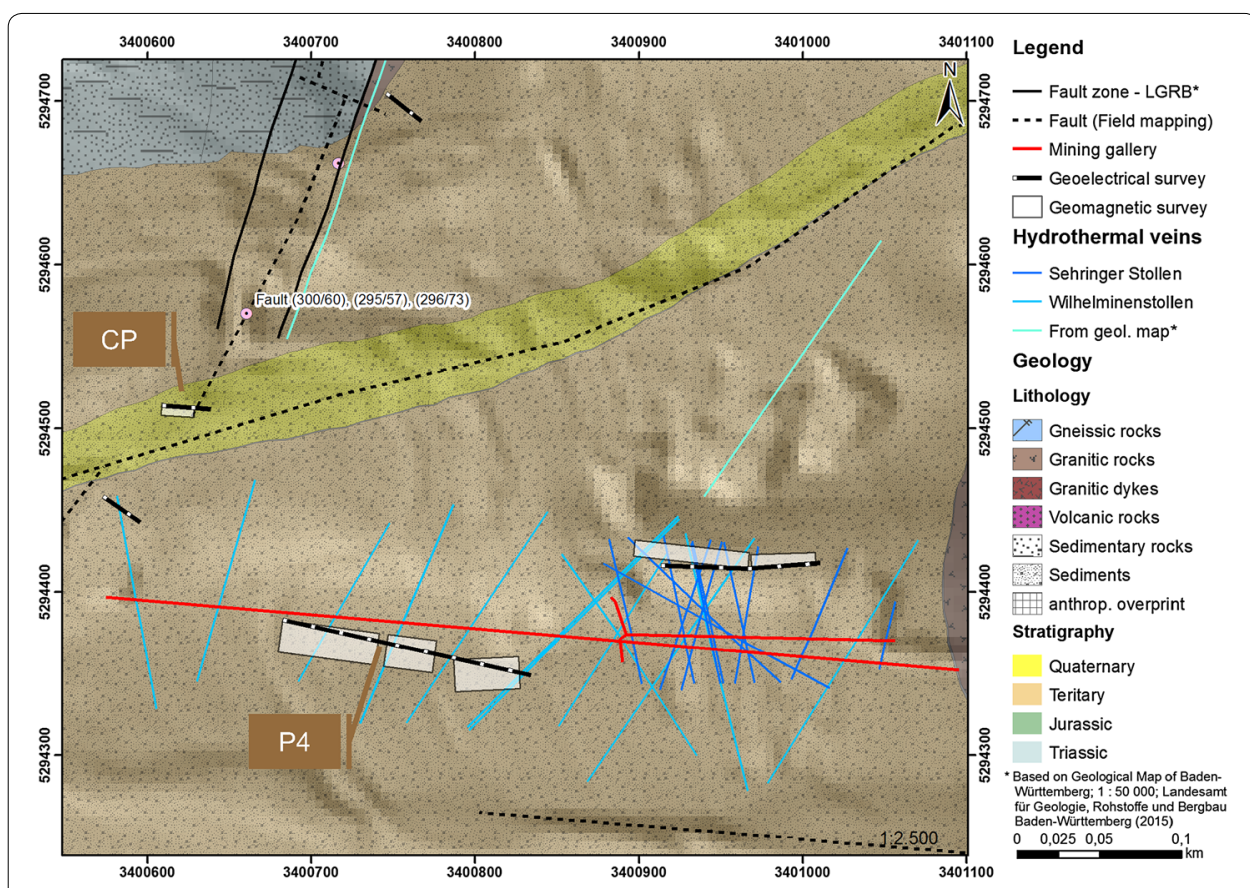

Fig. 11 Distribution of faults near the Wilhelminenstollen and veins (blue lines) observed in the Wilhelminenand Sehringer Stollen (red lines) and extrapolated to the geophysical measurement areas (geo-magnetics) and profiles (geo-electrics). CP calibration profile (Fig. 13)

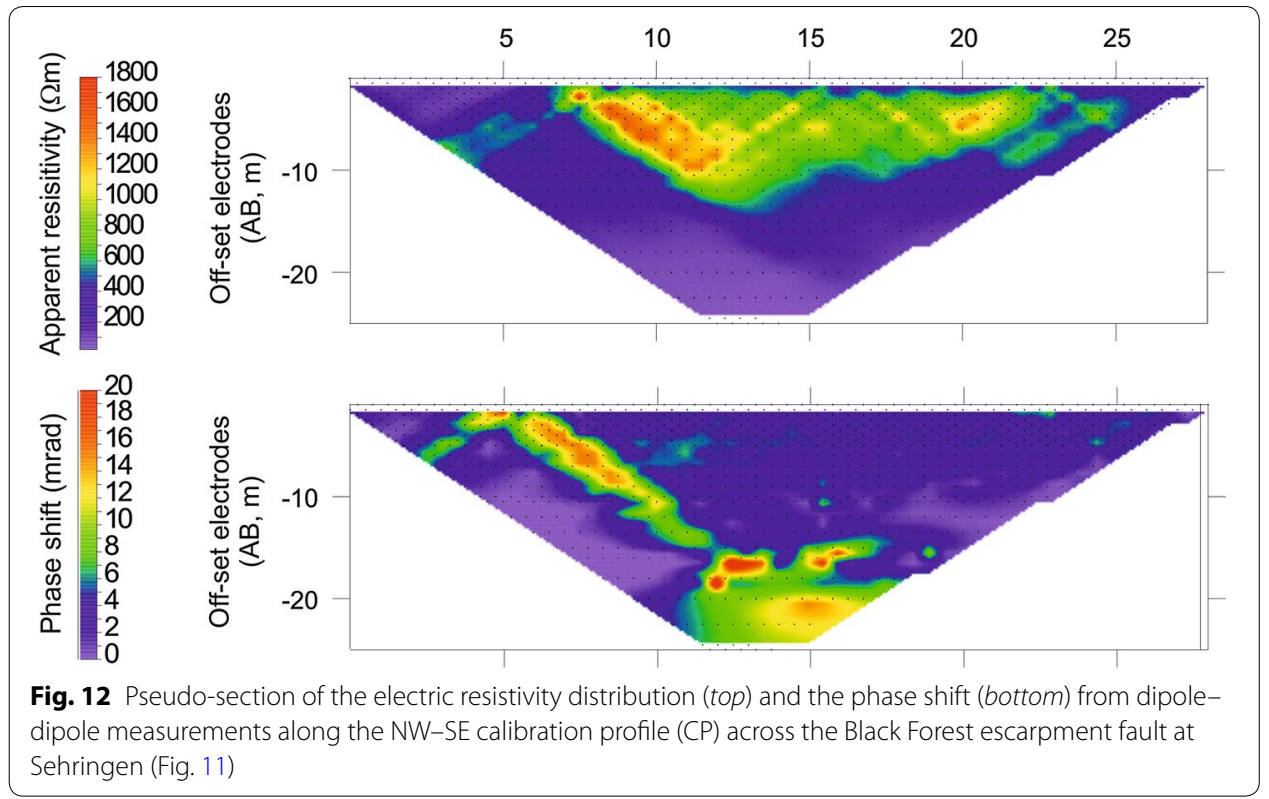

\section{Hydrogeology}

Hydraulic tests performed in the granitic basement of the southern Black Forest suggest hydraulic conductivities of the order of $4.5 \cdot 10^{-8} \mathrm{~m} \mathrm{~s}^{-1}$ at $500 \mathrm{~m}$ depth. Fluids from the near-surface granitic basement exhibit similar $\mathrm{Ca}$ - or $\mathrm{Na}-\mathrm{HCO}_{3}$-dominated chemical characteristics (Fig. 14). Near-surface waters generally are of low mineralisation. TDS increases with increasing depth, as indicated by the three analyses from Bad Säckingen. 


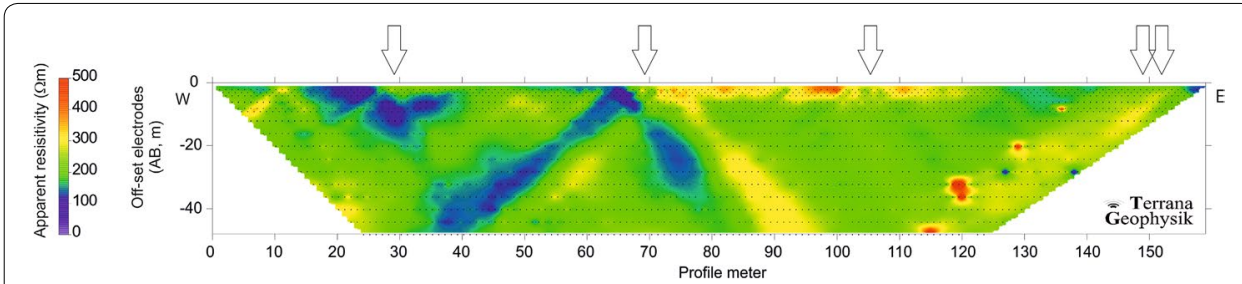

Fig. 13 Electric resistivity distribution along profile P4 (Fig. 11). Arrows indicate the extrapolation of the hydrothermal veins mapped in the Wilhelminenstollen to the surface assuming a constant dip between $45^{\circ}$ and $60^{\circ}$

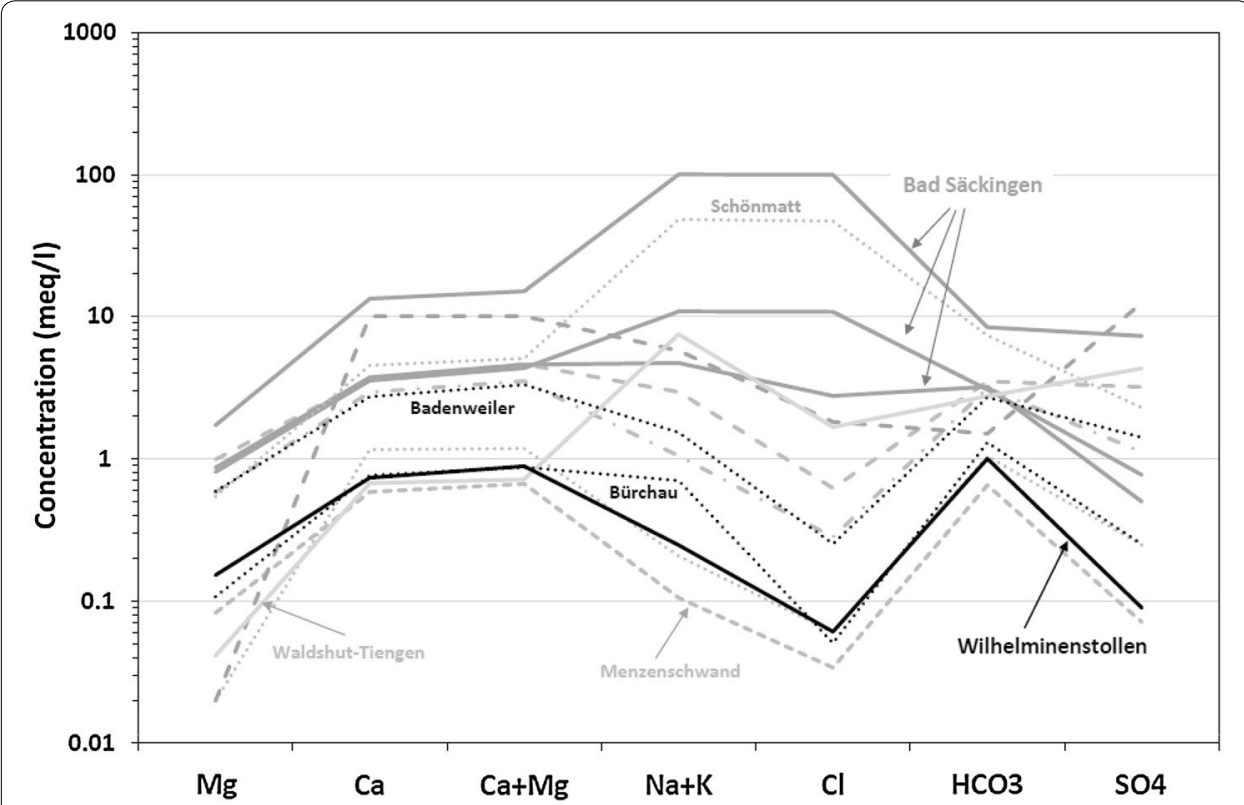

Fig. 14 Chemical composition of selected water samples from the southern Black Forest reveals increasing ion-concentration and water type changes from near-surface $\mathrm{Ca}^{-} \mathrm{HCO}_{3}$-type (e.g. Wilhelminenstollen, Menzenschwand, Bürchau) (Rolker et al. 2015 and this study) to an Na-Cl water-type (different depth sections in Bad Säckingen and Schönmatt, data from Stober (1995), Stober and Bucher (2014), and Rolker et al. (2015)

The deepest well $(600 \mathrm{~m})$ shows the highest TDS and is dominated by $\mathrm{Na}-\mathrm{Cl}$, whereas both TDS and $\mathrm{NaCl}$ decrease at shallower depth. Near-surface waters $(<100 \mathrm{~m})$, in general, possess low TDS values and water chemistry is dominated by $\mathrm{Ca}$ and $\mathrm{HCO}_{3}$ (e.g. Menzenschwand, Wilhelminenstollen). However, also thermal spring waters often have a near-surface water component (Fig. 14, e.g. Badenweiler, Bürchau). In contrast to Bürchau, the water from the Wilhelminenstollen has significantly lower $\mathrm{Na}$ and $\mathrm{SO}_{4}$ concentrations. In Badenweiler and Bürchau, low mineralisation and maximum sulphate equilibrium temperatures of about $60-80{ }^{\circ} \mathrm{C}$ indicate a small potential for water-rock interaction only (Rolker et al. 2015).

The relationship between $\delta^{18} \mathrm{O}$ and $\delta^{2} \mathrm{H}$ of thermal springs from different sites in the southern Black Forest is shown in Fig. 15. The isotope ratio follows the global meteoric water line. The values from Bürchau and Badenweiler show differences between sampling campaigns 1 and 2. The values from Wilhelminenstollen (sampling campaign 3, this study) lie between the above values. A shift towards higher $\delta^{18} \mathrm{O}$ values in campaign 


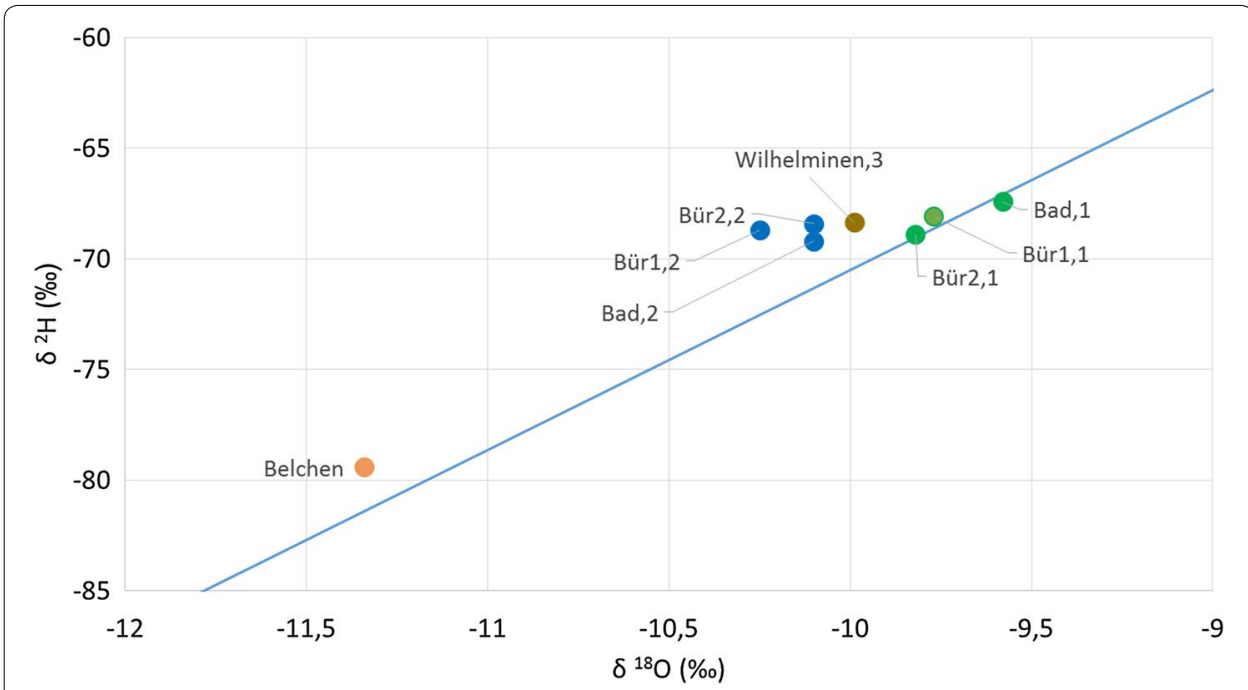

Fig. $15 \mathrm{H} / \mathrm{O}$-isotope distribution of the Wilhelminenstollen water (this study) in comparison with data from adjacent waters of the southern Black Forest from Badenweiler and Bürchau (Rolker et al. 2015)

2 was attributed to a higher contribution of rainwater. The difference in $\delta^{18} \mathrm{O}$ and $\delta^{2} \mathrm{H}$ values between the Mt. Belchen and the sites of Bürchau, Badenweiler, and Wilhelminenstollen along the meteoric water line can be attributed to altitude effects, since there is a difference in altitude of several hundred metres between the sites and Mt. Belchen. Following earlier studies of Pearson et al. (1991), a local relationship is identified, including the southern Black Forest in the area of Bürchau. For Mt. Belchen, the best fit between this relationship and true infiltration elevation was obtained from $\delta^{18} \mathrm{O}$ values. This gives a minimum infiltration altitude for the Wilhelminenstollen of about 730 masl. The hydrochemical data on Wilhelminenstollen, its minimum infiltration altitude, and the topographic situation result in a locally controlled hydrogeological framework with a maximum catchment area of $0.5 \mathrm{~km}^{2}$.

\section{Stress model for the topographic condition}

Local stress in mountain areas is affected by the topography, the rheological properties of the rock, and the ambient tectonic state of stress. Geometry and mass of the topography may cause local reorientation and lateral variation of the magnitude of the principal stress directions (Miller and Dunne 1996; Pan et al. 1995; Savage and Morin 2002). Since GeoLaB aims at approximating reservoir condition best, the URL design strives for rather topography-independent conditions of the stress field.

Rock type and ambient stress state are rather homogenous across the planned Geo$\mathrm{LaB}$ tunnel and hence to solely assess the influence of topography on the stress field distribution near the Wilhelminenstollen, a finite element was generated for an area of $19 \times 20 \mathrm{~km}$ around the Wilhelminenstollen (Fig. 6b) with a vertical extension from the topography down to $5 \mathrm{~km}$ b.s.l. (Fig. 16). First-order geomechanical modelling using ABAQUS๑ covers gravitational loading of the 3D model only. The resulting orientation and magnitude of the principal stress component are shown in Fig. 16. 


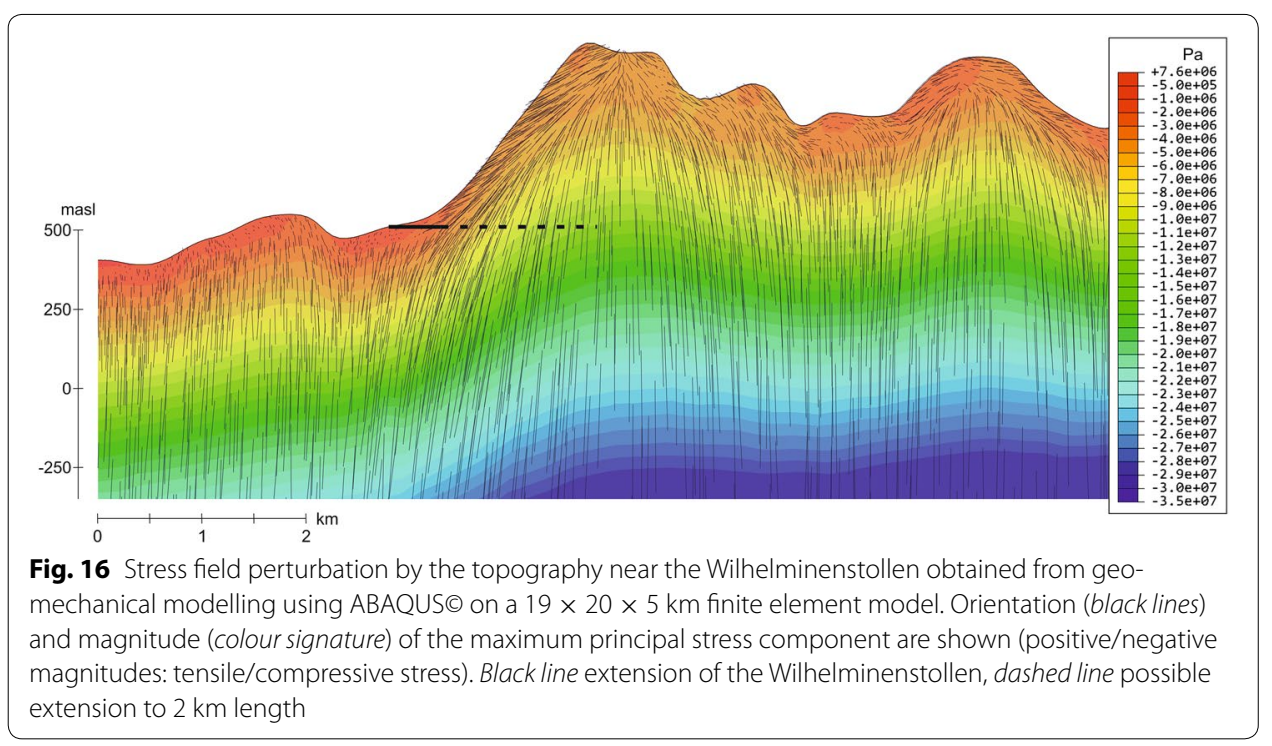

Close to the surface, both, orientation and magnitude of the maximum principal stress component are strongly influenced by the topography. At steep slopes and shallow depth (first 100-200 m), the maximum principal stress component significantly deviates from vertical orientation due to topographic stresses. Here, the vertical component of the stress tensor is no longer a principal stress. As a result, failure conditions and fracture patterns in these areas deviate significantly from regional trends. Consequently, regional stress field models are no longer applicable to predict of the reactivation potential of faults and fractures. Subvertical orientation of the maximum principal stress component is observed below ridges and plateaus and at considerable depth beneath strong topographic gradients only. Note that the modelled local stress field changes significantly, when superposing on the gravitational stress field the ambient compressive far-field tectonic stress. At this early planning stage of GeoLaB, this more comprehensive model hampers evaluation of the stress perturbations that are purely driven by topography, but it will be considered for the design of the tunnel.

The onset of the Wilhelminenstollen is located at the foot of Mt. Blauen. With its current length of about $500 \mathrm{~m}$, it is located entirely in the critical near-surface zone of highly perturbed stress states. For the specific setting of the Wilhelminenstollen, a tunnel length of $>1.5 \mathrm{~km}$ is suggested when considering the criteria of stress perturbation of $<1 \mathrm{MPa}$ and approaching vertical orientation of the maximum principal stress direction for gravity. This results in a minimum overburden of about $500 \mathrm{~m}$.

\section{Conclusion}

Particular aspects of geothermal characterisation and operation can only be obtained through access to the underground environment. Engineering of geothermal production from fractured crystalline rocks using flow rates of more than $30 \mathrm{~L} \mathrm{~s}^{-1}$ requires knowledge of geological, physical, and chemical processes that can be gained partly on the downhole field scale and partly by large-scale research laboratory facilities. 
As was pointed out by the NEA (2013), URLs provide important technical knowledge and increase confidence in the process of facility siting and design, engineering support, and evaluation of safety. Clearly, such a generic URL will not have all real reservoir conditions (such as temperature, magnitude of stress components, and chemical composition of water), but confidence in the suitability of a potential geological environment and engineering feasibility can be gained by a verification of individual processes and operation concepts. URLs offer an unparalleled opportunity to demonstrate the engineering concept of EGS and instil confidence in the wide range of stakeholders. A transparent underground experimentation and operation programme of an URL platform will yield specific information that also is of direct relevance to authorities assessing the risk of underground utilisation. In this context, a geothermal URL represents a worldwide unique research installation with specific environmental settings being required for EGS development.

Four criteria have been established based on EGS experience and applied to existing generic URLs. These are a relatively homogenous crystalline basement matrix with a well-connected fracture network with fracture transmissivities in the range of $>10^{-4} \mathrm{~m}^{2} \mathrm{~s}^{-1}$. Fractures should be characterised by hydrothermal alteration including illite and smectite among others. The local stress field is characterised by strike-slip (to normal faulting) reactivation and fractures are favourably oriented. Furthermore, the stress field is rather homogeneous with a variation in magnitude $<1 \mathrm{MPa}$ across the envisaged experimental volume. Obviously, a geothermal URL will not match reservoir conditions in terms of temperature, rock-water interaction, and the stress field. CHFEs that address these parameters will rather study gradients of these fields.

Application of the four criteria to existing generic URLs in the crystalline basement worldwide reveals that apart from the inferred stress field, the Äspö HRL, and apart from overburden, the Lindau Test Site, provide favourable conditions for CHFEs. These URLs may be used to carry out specific accompanying or complementary experiments.

Typical deep geothermal reservoir rocks of the URG are exposed in the Black Forest. In general, tectonic, geological, and hydrogeological conditions in the southern Black Forest match the established criteria for CHFEs in a geothermal URL. In the Wilhelminenstollen, controllable hydraulic boundary conditions are valid. An exploration concept to pre-characterise suitable GeoLaB sites in the Black Forest from the surface has been tested successfully. It involves exploration from the surface and aims at a first assessment of the established criteria in the run-up of large exploration including exploration wells. In this respect, the Wilhelminenstollen area is characterised as follows:

- A dense fracture network inferred from lineament analyses is completed by observations in the existing tunnel and resistivity measurements.

- Alteration zones with clay minerals or ore mineralisation in fractures are characterised well by electric resistivity.

- Hydraulically active fractures and fault zones in a regional network are identified at several sites in the Black Forest. In the absence of wells, local transmissivities cannot be acquired, but a typical natural in-flow into the tunnel of several $\mathrm{L} \mathrm{s}^{-1}$ can be estimated. Increasing TDS and higher $\mathrm{NaCl}$ concentration are expected. 
- Low influence of topography-induced stress variations requires a minimum overburden of about $500 \mathrm{~m}$.

- Regional reactivation potential is highest for large differential stresses. At Wilhelminenstollen, they are maximum for fractures and faults oriented $\mathrm{N} 110^{\circ} \mathrm{E}$ and $\mathrm{N} 170^{\circ} \mathrm{E}$.

The analysis performed has provided key steps for developing a generic URL in the southern Black Forest. In first order, most of the criteria are fulfilled in the study area. For a final decision on the technical feasibility of GeoLaB at Wilhelminenstollen as well as the conceptualisation and optimisation of the design, a large geophysical exploration campaign as well as exploration wells including hydraulic testing is necessary.

\section{Authors' contributions}

ES reviewed the condition of the Soultz EGS site and the exisitng URLs and carried out the fluid chemical analyses and the geophysical surveys, JM carried out the remote sensing and slip- and dilation tendency analyses, CM contributed to the review of the Soultz EGS site and the existing URLS, MG reviewed the exiting mines in Black Forest and performed the numerical simulation on the influence of topography, JG reviewed the geological condition of the Black Forest, IS reviewed the hydrogeological condition and TK summarized the scientific concept of GeoLaB. All authors established the criteria. All authors read and approved the final manuscript.

\section{Author details}

1 Institute for Nuclear Waste Disposal, Karlsruhe Institute of Technology, Hermann-von-Helmholtz-Platz 1 ,

76128 Karlsruhe, Germany. ${ }^{2}$ Geothermal Research Group, Institute of Applied Geosciences, Karlsruhe Institute of Technology, Adenauerring 20b, 76131 Karlsruhe, Germany.

\section{Acknowledgements}

This study was carried out in the framework of the HGF portfolio project "Geoenergy" under the Helmholtz topic "Geothermal Energy Systems". We would like to thank I. Blechschmidt (Nagra, Switzerland), R. Christiansson (SKB, Sweden) and J. Pacovsky (Centre of Experimental Geotechnics, Czech Republic) for detailed information on their URLs. F. Nitschke and E. Eiche (KIT, Germany) kindly measured and evaluated the hydrochemical data of Wilhelminenstollen. G. Markl (University of Tübingen, Germany) kindly commented on the condition of the pre-selected mines in the southern Black Forest. M. Waldhör and A. Patzelt (Terrana Geophysik, Germany) are acknowledged for the geophysical field measurements. A. Steudel (KIT, Germany) kindly provided analyses on clay minerals.

\section{Competing interests}

The authors declare that they have no competing interests.

Received: 27 January 2016 Accepted: 20 May 2016

Published online: 07 June 2016

\section{References}

Baillieux P, Schill E, Abdelfettah Y, Dezayes C. Possible natural fluid pathways from gravity pseudo-tomography in the geothermal fields of Northern Alsace (Upper Rhine Graben). Geotherm Energy J. 2014;2(16):1-14.

Baillieux P, Schill E, Edel JB, Mauris G. Localization of temperature anomalies in the Upper Rhine Graben: insights from geophysics and neotectonic activity. Int Geol Rev. 2013;55(14):1744-62.

Barton N, Bandis S, Bakhtar K. Strength, deformation and conductivity coupling of rock joints. Int J Rock Mech Min Sci Geomech. 1985;22(3):121-40. doi:10.1016/0148-9062(85)93227-9.

Bayer M. Die Himmelfahrt Fundgrube. Ein Führer durch das Lehr_und Besucherbergwerk der TU Bergakademie Freiberg. Freiberg: TU Bergakademie Freiberg; 1998.

Bons PD, Fusswinkel T, Gomez-Rivas E, Markl G, Wagner T, Walter B. Fluid mixing from below in unconformity-related hydrothermal ore deposits. Geology. 2014;42(12):1035-8. doi:10.1130/g35708.1.

Brady BHG, Brown ET. Rock mechanics: for underground mining. Springer Science \& Business Media 2013.

Brockamp O, Schlegel A, Wemmer K. Complex hydrothermal alteration and illite K-Ar ages in Upper Visean molasse sediments and magmatic rocks of the Variscan Badenweiler-Lenzkirch suture zone, Black Forest, Germany. Int J Earth Sci. 2015;104(3):683-702.

Brown DW. Hot dry rock geothermal energy: important lessons from Fenton Hill. In: Proceedings of the thirty-fourth workshop on geothermal reservoir engineering. Stanford: Stanford University; 2009.

Bucher K, Stober I. The composition of groundwater in the continental crystalline crust. In: Stober I, Bucher K, editors. Hydrogeology in crystalline rocks. Dordrecht: KLUWER academic Publishers; 2000. p. 141-76.

Cornet F, Bérard T, Bourouis S. How close to failure is a granite rock mass at a 5 km depth? Int J Rock Mech Min Sci. 2007;44(1):47-66.

Cuenot N, Frogneux M, Dorbath C, Calo M. Induced microseismic activity during recent circulation tests at the EGS site of Soultz-sous-Forêts (France). In: Proceedings of the 36th workshop on geothermal reservoir engineering. 2011.

Davison CC. Monitoring hydrogeologlcal conditions in fractured rock at the site of Canada's Underground Research Laboratory. Ground Water Monit Rem. 1984;4(4):95-102. doi:10.1111/j.1745-6592.1984.tb00899.x. 
Dezayes C, Genter A, Hooijkaas GR. Deep-seated geology and fracture system of the EGS Soultz reservoir (France) based on recent $5 \mathrm{~km}$ depth boreholes. Proceedings, paper 1612 pdf. 2005.

Eisbacher GH, Lüschen E, Wickert F. Crustal-scale thrusting and extension in the Hercynian Schwarzwald and Vosges, central Europe. Tectonics. 1989;8(1):1-21. doi:10.1029/TC008i001p00001.

Evans KF, Genter A, Sausse J. Permeability creation and damage due to massive fluid injections into granite at $3.5 \mathrm{~km}$ at Soultz: 2. Critical stress and fracture strength. J Geophys Res. 2005;110:B04204. doi:10.1029/2004JB003169.

Franzke HJ, Werner W, Wetzel H-U. Die Anwendung von Satellitenbilddaten zur tektonischen Analyse des Schwarzwalds und des angrenzenden Oberrheingrabens. Jh Landesamt für Geologie Rohstoffe und Bergbau Baden-Württemberg LGRB. 2003;39:25-54.

Freeze RA, Javandel I. An interview with Paul Witherspoon, distinguished hydrogeologist from the USA. Hydrogeol J. 2008;16:811-5.

Garnish J. European activities in Hot Dry Rock research. Paper presented at the open meeting on enhanced geothermal systems. Reno; 2002.

Gaucher E, Schoenball M, Heidbach O, Zang A, Fokker P, van Wees J-D, Kohl T. Induced seismicity in geothermal reservoirs: a review of forecasting approaches. Renew Sustain Energy Rev. 2015;52:1473-90. doi:10.1016/j. rser.2015.08.026.

Geiermann J, Schill E. 2-D Magnetotellurics at the geothermal site at Soultz-sous-Forêts: resistivity distribution to about 3000 m depth. Comptes Rendus Geoscience. 2010;342:587-99.

Genter A, Castaing C. Scale effects in the fracturing of granite. Comptes Rendus De L Academie Des Sciences Serie li Fascicule a-Sciences De La Terre Et Des Planetes. 1997;325(6):439-45.

Genter A, Traineau H, Ledésert B, Bourgine B, Gentier S. Over 10 years of geological investigations withing the HDR Soultz Project, France. In: World Geothermal Congress. 2000. p. 3706-12.

Glodny J, Grauert B. Evolution of a hydrothermal fluid-rock interaction system as recorded by Sr isotopes: a case study from the Schwarzwald, SW Germany. Mineral Petrol. 2009;95(3-4):163-78.

Grimmer JC, Ritter JRR, Eisbacher GH, Fielitz W. The late Variscan control on the location and asymmetry of the Upper Rhine Graben. Int J Earth Sci. 2016. doi:10.1007/s00531-016-1336-x.

Hakami E, Min K-B. Modelling of the state of stress, preliminary site description Laxemar subarea-version 1.2. Report vol R-06-17. Stockholm: Svensk Kärnbränslehantering; 2009.

Hakami H. Äspö Hard Rock Laboratory, update of the rock mechanical model 2002. International progress report vol IPR03-37. Stockholm: Svensk Kärnbränslehantering; 2003.

Hess JC, Hanel M, Arnold M, Gaiser A, Prowatke S, Stadler S, Kober B. Variscan magmatism at the northern margin of the Moldanubian Vosges and Schwarzwald I. Ages of intrusion and cooling history. Eur J Mineral. 2000;12:79.

Hettkamp T, Baumgärtner J, Baria R, Gerard A, Gandy T, Michelet S, Teza D. Electricity production from hot rocks. In: Proceedings, 29th workshop on geothermal reservoir engineering, California: Stanford University; 2004. p. 26-8.

Himmelsbach T, Hötzl H, Maloszewski P. Solute transport processes in a highly permeable fault zone of Lindau Fractured Rock Test Site (Germany). Ground Water. 1998;36(5):792-800. doi:10.1111/j.1745-6584.1998.tb02197.x.

Himmelsbach T, Shao H, Wieczorek W, Flach D, Schuster K, Alheid H-J, Liou T-S, Bartlakowski J, Krekeler T. Effective field parameter EFP (Grimsel). Wettingen: Nagra; 2003.

Hoefs J, Emmermann R. The oxygen isotope composition of Hercynian granites and pre-Hercynian gneisses from the Schwarzwald, SW Germany. Contrib Miner Petrol. 1983;83:320-9.

Huber M, Huber-Aleffi A. Das Kristallin des Südschwarzwaldes: NTB 84-30. NTB. 1984.

Jung R. EGS—goodbye or back to the future 95. Effective and sustainable hydraulic fracturing. Rijeka: InTech; 2013.

Jung R, Willis-Richard J, Nicholls J, Bertozzi A, Heinemann B. Evaluation of hydraulic tests at Soultz-sous-Forêts, European HDR Site. In: Proceedings of the world geothermal congress. 1995. p. 2671-76.

Kalt A, Altherr R. Metamorphic evolution of garnet-spinel peridotites from the Variscan Schwarzwald (Germany). Geol Rundsch. 1996;85(2):211-24.

Klee G, Rummel F. Rock stress measurements in the Äspö HRL, hydraulic fracturing in boreholes KA2599G01 and KF0093A01, vol. IPR-02-02. Stockholm: Svensk Kärnbränslehantering AB; 2002.

Kneer S. Geochemische Untersuchungen der Gangartmineralisationen im Bergbaurevier Badenweiler-Sehringen. Diploma Thesis, Eberhard Karls Universität. 2006.

Kober B, Kalt A, Hanel M, Pidgeon RT. SHRIMP dating of zircons from high-grade metasediments of the Schwarzwald/SW-Germany and implications for the evolution of the Moldanubian basement. Contrib Miner Petrol. 2004;147(3):330-45.

Kohl T, Bächler D, Rybach L. Steps towards a comprehensive thermo-hydraulic analysis of the HDR test site Soultz-sousForêts. In: Proceedings World Geothermal Congress. 2000. p. 2671-76.

Kohl T, Evans K, Hopkirk R, Jung R, Rybach L. Observation and simulation of non-Darcian flow transients in fractured rock. Water Resour Res. 1997;33(3):407-18.

Kolditz O, Görke U-J, Shao H, Wang W. Thermo-hydro-mechanical-chemical processes in porous media. Berlin: Springer; 2012.

Komulainen J, Hurmerinta E, Pöllänen J. Monitoring measurements by the difference flow methods during the year 2011 , drillholes OL-KR41, -KR42, KR45, -KR46 and ONK-KR13. Eurajoki: Posiva; 2014.

Krecher M, Behrmann JH. Tectonics of the Vosges (NE France) and the Schwarzwald (SW Germany): evidence from Devonian-Carboniferous active margin basins and their deformation. Geotecton Res. 2007;95(1):61-86.

Krohe A, Eisbacher GH. Oblique crustal detachment in the Variscan Schwarzwald, southwestern Germany. Geol Rundsch. 1988;77(1):25-43. doi:10.1007/bf01848674.

Kumazaki N, Ikeda K, Goto J, Mukai K, Iwatsuki T, Furue R. Synthesis of the shallow borehole investigations at the MIU construction site. Tech. Rep. TN7400. Ibaraki: Japan Nuclear Cycle Development Institute; 2003.

Ledésert B, Berger G, Meunier A, Genter A, Bouchet A. Diagenetic-type reactions related to hydrothermal alteration in the Soultz-sous-Forets granite, France. Eur J Mineral. 1999;11(4):731-41. doi:10.1127/ejm/11/4/0731.

Ledésert B, Hebert R, Genter A, Bartier D, Clauer N, Grall C. Fractures, hydrothermal alterations and permeability in the Soultz enhanced geothermal system. C R Geosci. 2010;342(7):607-15. 
Marschall HR, Kalt A, Hanel M. P-T evolution of a Variscan lower-crustal segment: a study of granulites from the Schwarzwald, Germany. J Petrol. 2003;44(2):227-53.

Massart B, Paillet M, Henrion V, Sausse J, Dezayes C, Genter A, Bisset A. Fracture characterization and stochastic modeling of the granitic basement in the HDR Soultz Project (France). In: World Geothermal Congress. 2010.

Meixner J, Schill E, Grimmer JC, Gaucher E, Kohl T, Klingler P. Structural control of geothermal reservoirs in extensional tectonic settings: an example from the Upper Rhine Graben. J Struct Geol. 2016;82:1-15.

Meller C, Kohl T. The significance of hydrothermal alteration zones for the mechanical behavior of a geothermal reservoir. Geothermal Energy. 2014;2(12):21. doi:10.1186/s40517-014-0012-2.

Meller C, Kontny A, Kohl T. Identification and characterization of hydrothermally altered zones in granite by combining synthetic clay content logs with magnetic mineralogical investigations of drilled rock cuttings. Geophys $\mathrm{J}$ Int. 2014;199(1):465-79. doi:10.1093/gji/ggu278.

Miller DJ, Dunne T. Topographic perturbations of regional stresses and consequent bedrock fracturing. J Geophys Res B Solide Earth. 1996;101(B11):25523-36.

MIT. The future of geothermal energy, impact of enhanced geothermal systems (EGS) on the United States in the 21st century. Cambridge: Massachusetts Institute of Technology; 2006.

Nami P, Schellschmidt R, Schindler M, Tischner T. Chemical stimulation operations for reservoir development of the deep crystalline HDR/EGS system at Soultz-sous-Forêts (France). In: Proceedings, 32nd workshop on geothermal reservoir engineering. California: Stanford University; 2008. p. 28-30.

National Academies of Sciences E and Medicine. Characterization, modeling, monitoring, and remediation of fractured rock. Washington: The National Academies Press; 2015.

Nea NEA. Underground research laboratories (URL). Radioactive waste management. OECD/NEA: Paris; 2013.

Pan E, Amadei B, Savage WZ. Gravitational and tectonic stresses in anisotropic rock with irregular topography. Int J Rock Mech Min Sci Geomech. 1995;32(3):201-14. doi:10.1016/0148-9062(94)00046-6.

Pearson F, Balderer W, Loosli H, Lehmann B, Matter A, Peters T, Schmassmann H, Gautschi RU. Applied isotope hydrogeology: a case study in northern Switzerland. AAmsterdam: Elsevier; 1991.

Pribnow DFC. The deep thermal regime in Soultz and implications for fluid flow. GGA Report. Hannover: GGA Institut; 2000.

Rehn I, Gustafson G, Stanfors R, Wikberg P. ÄSPÖ HRL—Geoscientific evaluation 1997/5. Models based on site characterization. Technical report, vol TR-97-06. Stockholm: Svensk Kärnbränslehantering AB; 1997.

Rolker J, Schill E, Stober I, Schneider J, Neumann T, Kohl T. Hydrochemical characterisation of a major central European heat flux anomaly: the Bürchau geothermal spring system, Southern Black Forest, Germany. Geotherm Energy. 2015;3(1):1-18.

Rummel F, König E. Density, ultrasonic velocities and magnetic susceptibility measurements on the core material from borehole EPS1 at Soultz-sous-Forêts'. Internal report, vol 8. Bochum: Ruhr-Universität; 1991.

Sausse J. Hydromechanical properties and alteration of natural fracture surfaces in the Soultz granite (Bas-Rhin, France). Tectonophysics. 2002;348(1-3):169-85. doi:10.1016/s0040-1951(01)00255-4.

Sausse J, Dezayes C, Dorbath L, Genter A, Place J. 3D model of fracture zones at Soultz-sous-Forêts based on geological data, image logs, induced microseismicity and vertical seismic profiles. C R Geosci. 2010;342(7):531-45.

Sausse J, Fourar M, Genter A. Permeability and alteration within the Soultz granite inferred from geophysical and flow log analysis. Geothermics. 2006;35(5-6):544-60. doi:10.1016/j.geothermics.2006.07.003.

Sausse J, Genter A. Types of permeable fractures in granite. Geol Soc London Spec Publ. 2005;240(1):1-14. doi:10.1144/ gsl.sp.2005.240.01.01.

Savage WZ, Morin RH. Topographic stress perturbations in southern Davis Mountains, west Texas 1. Polarity reversal of principal stresses. J Geophys Res B Solid Earth. 2002;107(12):5-15.

Sawatzki G, Hann HP, Groschopf R, Villinger E. Badenweiler-Lenzkirch-Zone (Südschwarzwald): Erläuterungen mit Hinweisen für Exkursionen. 1. Ausg. zur 2., überarb. Ausg. d. Geolog. Karte edn. Landesamt für Geologie. Freiburg: Rohstoffe und Bergbau Baden-Württemberg; 2003.

Schaltegger U. U-Pb geochronology of the Southern Black Forest Batholith (Central Variscan Belt): timing of exhumation and granite emplacement. Int J Earth Sci. 2000;88(4):814-28. doi:10.1007/s005310050308.

Schill E, Genter A, Kohl T, Cuenot N. Enhancement of productivity in the Soultz EGS site by 20 hydraulic and chemical stimulation experiments and long-term circulation. In: Proceedings World Geothermal Congress 2015, 19-25 April 2015. Melbourne; 2015.

Schindler M, Baumgärtner J, Gandy T, Hauffe P, Hettkamp T, Menzel H, Penzkofer P, Teza D, Tischner T, Wahl G. Successful hydraulic stimulation techniques for electric power production in the Upper Rhine Graben, Central Europe. In: World Geothermal Congress, 25-29 April 2010, Bali; 2010.

Schleicher A, Warr L, Kober B, Laverret E, Clauer N. Episodic mineralization of hydrothermal illite in the Soultz-sous-Forêts granite (Upper Rhine Graben, France). Contrib Miner Petrol. 2006;152(3):349-64. doi:10.1007/s00410-006-0110-7.

Schoenball M, Baujard C, Kohl T, Dorbath L. The role of triggering by static stress transfer during geothermal reservoir stimulation. J Geophys Res Solid Earth. 2012;117(B9):B09307. doi:10.1029/2012jb009304.

Schumacher ME. Upper Rhine Graben: role of preexisting structures during rift evolution. Tectonics. 2002;21 (1):1006. doi: $10.1029 / 2001$ tc900022.

Sehlstedt S, Strahle A. Identification of water conductive oriented fractures in the boreholes KASO2 and KAS06, vol. PR 25-91-11. Stockholm: Svensk Kärnbränslehantering AB; 1991.

Simon K. Hydrothermal alteration of Variscan granites, southern Schwarzwald, Federal Republic of Germany. Contrib Miner Petrol. 1990;105:177-96.

Stanfors R, Rhén I, Tullborg E-L, Wikberg P. Overview of geological and hydrogeological conditions of the Äspö hard rock laboratory site. Appl Geochem. 1999;14(7):819-34. doi:10.1016/s0883-2927(99)00022-0.

Steen H. Geschichte des modernen Bergbaus im Schwarzwald: Eine detaillierte Zusammenstellung der Bergbauaktivitäten von 1890 bis zum Jahr 2000. 1st ed. Norderstedt: Books on Demand GmbH; 2004.

Stephansson O, Ljunggren C, Jing L. Stress measurements and tectonic implications for Fennoscandia. Tectonophysics. 1991;189(1):317-22. 
Stober I. Die Wasserführung des kristallinen Grundgebirges. Ferdinand Enke Verlag:191. 1995.

Stober I, Bucher K. Herkunft der Salinität in Tiefenwässern des Grundgebirges-unter besonderer Berücksichtigung der Kristallinwässer des Schwarzwaldes. Grundwasser. 2000;5(3):125-40.

Stober I, Bucher K. Hydraulic properties of the crystalline basement. Hydrogeol J. 2007;15(2):213-24. doi:10.1007/ s10040-006-0094-4.

Stober I, Bucher K. Hydraulic conductivity of fractured upper crust: Insights from hydraulic tests in boreholes and fluidrock interaction in crystalline basement rocks. 2014. Geofluids:n/a-n/a. doi:10.1111/gfl.12104.

Todt W. Zirkon U/Pb-Alter des Malsburg-Granits vom Südschwarzwald. J Mineral Geochem. 1976;12:532-44.

Valley B, Evans KF. Stress state at Soultz-sous-Forêts to $5 \mathrm{~km}$ depth from wellbore failure and hydraulic observations. In: 32nd workshop on geothermal reservoir engineering. 2007.

Wennberg OP, Casini G, Jonoud S, Peacock DC. The characteristics of open fractures in carbonate reservoirs and their impact on fluid flow: a discussion. Pet Geosci. 2016. doi:10.1144/petgeo2015-003.

Werner W, Dennert V. Lagerstätten und Bergbau im Schwarzwald. Freiburg: LGRB; 2004.

Wickert F, Altherr R, Deutsch M. Polyphase Variscan tectonics and metamorphism along a segment of the Saxothuringian-Moldanubian boundary: the Baden-Baden Zone, northern Schwarzwald (F.R.G.). Geol Rundsch. 1990;79(3):627-47.

Zimmerman RW, Yeo I-W. Fluid flow in rock fractures: From the Navier-Stokes equations to the cubic law. In: Faybishenko B, Witherspoon PA, Benson S, editors. Dynamics of fluids in fractured rock, vol. 122. Washington: American Geophysical Union; 2000. p. 213-24

Zoback MD, Kohli A, Das I, McClure MW. The importance of slow slip on faults during hydraulic fracturing stimulation of shale gas reservoirs. Society of Petroleum Engineers, SPE-155476-MS, SPE. 2012.

Zuther M, Brockamp O. The fossil geothermal system of the Baden-Baden trough (northern Black Forest, F.R. Germany). Chem Geol. 1988;71:337-53.

\section{Submit your manuscript to a SpringerOpen ${ }^{\circ}$ journal and benefit from:}

- Convenient online submission

\section{- Rigorous peer review}

- Immediate publication on acceptance

- Open access: articles freely available online

- High visibility within the field

- Retaining the copyright to your article

Submit your next manuscript at $\boldsymbol{\nabla}$ springeropen.com 